\title{
The role of beta-carotene in cancer prevention : epidemiological studies on cervical dysplasia
}

Citation for published version (APA):

de Vet, H. C. W. (1990). The role of beta-carotene in cancer prevention : epidemiological studies on cervical dysplasia. [Doctoral Thesis, Maastricht University]. Datawyse.

https://doi.org/10.26481/dis.19900608hv

Document status and date:

Published: 01/01/1990

DOI:

10.26481/dis.19900608hv

Document Version:

Publisher's PDF, also known as Version of record

\section{Please check the document version of this publication:}

- A submitted manuscript is the version of the article upon submission and before peer-review. There can be important differences between the submitted version and the official published version of record.

People interested in the research are advised to contact the author for the final version of the publication, or visit the DOI to the publisher's website.

- The final author version and the galley proof are versions of the publication after peer review.

- The final published version features the final layout of the paper including the volume, issue and page numbers.

Link to publication

\footnotetext{
General rights rights.

- You may freely distribute the URL identifying the publication in the public portal. please follow below link for the End User Agreement:

www.umlib.nl/taverne-license

Take down policy

If you believe that this document breaches copyright please contact us at:

repository@maastrichtuniversity.nl

providing details and we will investigate your claim.
}

Copyright and moral rights for the publications made accessible in the public portal are retained by the authors and/or other copyright owners and it is a condition of accessing publications that users recognise and abide by the legal requirements associated with these

- Users may download and print one copy of any publication from the public portal for the purpose of private study or research.

- You may not further distribute the material or use it for any profit-making activity or commercial gain

If the publication is distributed under the terms of Article $25 \mathrm{fa}$ of the Dutch Copyright Act, indicated by the "Taverne" license above, 


\section{THE ROLE OF BETA-CAROTENE IN CANCER PREVENTION}

Epidemiological studies on cervical dysplasia 


\title{
THE ROLE OF BETA-CAROTENE IN CANCER PREVENTION
}

\author{
Epidemiological studies on cervical dysplasia
}

\section{PROEFSCHRIFT}

\author{
ter verkrijging van de graad van doctor \\ aan de Rijksuniversiteit Limburg te Maastricht, \\ op gezag van de Rector Magnificus, Prof. Dr. F.I.M. Bonke, \\ volgens het besluit van het College van Dekanen, \\ in het openbaar te verdedigen \\ op vrijdag, 8 juni 1990 om 14.00 uur
}

door

Henrica Cornelia Wilhelmina de Vet

geboren te Gilze in 1956 


\title{
THE ROLE OF BETA-CAROTENE IN CANCER PREVENTION
}

Epidemiological studies on cervical dysplasia

\section{PROEFSCHRIFT}

\author{
ter verkrijging van de graad van doctor \\ aan de Rijksuniversiteit Limburg te Maastricht, \\ op gezag van de Rector Magnificus, Prof. Dr. F.I.M. Bonke, \\ volgens het besluit van het College van Dekanen, \\ in het openbaar te verdedigen \\ op vrijdag, 8 juni 1990 om 14.00 uur
}

door

Henrica Cornelia Wilhelmina de Vet

geboren te Gilze in 1956 
Promotores:

Prof. Dr. P.G. Knipschild

Prof. Dr. F. Sturmans

Beoordelingscommissie: Prof. Dr. J.W. Arends, R.L. (voorzitter)

Prof. Dr. H.J.A. Collette, R.U.U.

Prof. Dr. J.L.H. Evers, R.L.

Prof. Dr. F. ten Hoor, R.L.

Prof. Dr. W.A. van Staveren, L.U.W.

CIP-DATA KONINKLIJKE BIBLIOTHEEK, DEN HAAG

Vet, Henrica Cornelia Wilhelmina de

The role of beta-carotene in cancer prevention : epidemiological studies on cervical dysplasia / Henrica Cornelia Wilhelmina de Vet. - Maastricht :

Datawyse. - III. Thesis Maastricht. - With ref. - With summary in Dutch.

ISBN 90-5291-025.1

SISO 614.55 UDC 612.015.6:616-006.6-084(043.3) NUGI 742

Subject headings: epidemiology / neoplasms / carotene

Lay-out: Thum Aarts

Uitgave: Datawyse Meastricht

Omslagontwerp: Jan Eggen Maastricht

Druk: Krips Repro Meppel

Het onderzoek dat de grondslag vormt van dit proefschrift, werd verricht met financiële ondersteuning van de Nederlandse Kankerbestrijding.

In de drukkosten van het proefschrift werd bijgedragen door de Stichting Dr. Ir. J.H.J. van de Laar. 


\section{CONTENTS}

page

\section{Chapter 1}

Introduction

Chapter 2

The puzzling role of vitamin $A$ in cancer prevention

Chapter 3

The role of beta-carotene and other dietary factors in the etiology of cervical dysplasia: a case-control study

\section{Chapter 4}

The effect of beta-carotene on cervical dysplasia. Rationale and implications of a study design

Chapter 5

The effect of beta-carotene on the regression and progression of cervical dysplasia: a clinical experiment

Chapter 6

Interobserver variation in histopathological grading of cervical dysplasia

Chapter 7

Epilogue

Chapter 8

Summary

Chapter 9

Samenvatting

Dankwoord 



\section{Chapter 1}

\section{INTRODUCTION}

The central question of this thesis is whether dietary vitamin $A$, and especially its precursor beta-carotene, protects against cancer. Vitamin A consists of retinol and that part of some carotenoids that can be converted into retinol in the human body. There are other carotenoids which cannot be converted into retinol and thus have no vitamin A activity. Of the convertible carotenoids, beta-carotene is most efficiently converted into retinol. Because of its prevalence in many vegetables and fruits, it has been studied most extensively.

The epidemiological literature on vitamin $A$ and cancer clearly indicates that betacarotene is more likely to exert the cancer preventive effect than retinol (1). This conclusion is based on non-experimental studies, which nearly all point in the same direction: persons who developed cancer had a lower consumption of beta-carotene containing foods (chiefly vegetables and fruits) than persons without cancer, while the consumption of retinol containing foods did not differ. From a nutritional point of view, this observation would probably suffice to recommend a high consumption of vegetables and fruits. However, several reasons can be put forward why one might like to know which specific factor in vegetables and fruits is responsible for the cancer preventive effect, such as scientific curiosity or a wish to issue more detailed dietary guidelines for cancer prevention. Our motive for performing new studies was primarily methodological. We wanted to examine whether non-experimental epidemiological studies were right in suggesting that beta-carotene protects against cancer. In our opinion, non-experimental studies give some indjcations but no strong evidence that beta-carotene is causally related to cancer. This is due to biases that may be present in non-experimental studies, especially when dietary factors are under study. Experimental study designs can eliminate these biases. By way of background information for the studies presented in the next chapters, the validity of non-experimental and experimental studies will be discussed below.

\section{Validity of non-experimental studies}

The main types of biases that are present in non-experimental studies can be categorized as selection bias, information bias and confounding bias.

Selection bias is a distortion of the measured effect introduced by the selection of the study population. It leads to an estimation of the effect among subjects included in the study which is different from the estimate obtainable from the entire population theoreticaly targeted for the study (2). Dietary factors do not entail special problems with respect to selection bias. 
Information bias occurs whenever there are failures in the classification of subjects, either with respect to exposure or to diagnosis, due to errors in obtaining the required information. In studies of the role of dietary factors in the etiology of a disease, the consumption of food products or the intake of specific nutrients or other dietary components has to be assessed. For most people, food consumption is not a stable characteristic. People like to vary their meals, not only with respect to the products they eat, but also with respect to the quantities they consume. Moreover, the composition and nutrient content of agricultural products may vary with the seasons and the regions where they are grown. However, for epidemiological purposes it is usually not necessary to aim at quantitative precision. In qualitative studies, it suffices to classify individuals into categories of intake (3). Nevertheless, it cannot be avoided that some of the study subjects will be misclassified with respect to their exposure status. Random misclassification will lead to bias towards the null. Differences in systematic underreporting or overreporting for cases and controls may lead to either overestimation or underestimation of the effect.

Confounding bias is another type of bias that affects the validity of non-experimental studies. The estimate of the effect of the exposure of interest can be distorted, if it is mixed with the effect of extraneous factors. For an extraneous factor to be a confounder, this factor must be predictive of the occurrence of disease and show a correlation with the exposure under study, but must not be an intermediate step in the causal path between the exposure and the disease (2). Confounding may lead to overestimation or underestimation of an effect, depending on the direction of the associations that the confounding factor has with exposure and disease.

Confounding bias is a problem especially in studies on nutrition, as the intakes of some dietary factors are usually strongly correlated. If the correlation between dietary factors is very high (e.g. because they occur mainly in the same foods, or are frequently eaten together), proper adjustment in a multivariate analysis is impossible, and in that case there is no way to discriminate between the effects of these factors. This is a serious problem in non-experimental studies on dietary factors and cancer. Moreover, adjustment for confounding factors is only possible if these factors are well measured. If strong confounders are inadequately measured, considerable residual confounding may remain, which can mask weak effects of risk factors under study or lead to spurious associations. It is evident that adjustment can only be made for known and measured risk factors. Therefore, it cannot be precluded that an as yet unrecognized dietary factor, or another factor which correlates highly with the intake of beta-carotene, is responsible for the cancer preventive effect.

\section{Validity of experimental studies}

In a randomized experiment (randomized trial) the problems of selection bias, information bias and confounding bias can be eliminated by the study design. Randomization ensures the comparability of those groups in the study population which 
do and those which do not receive the active intervention. As a result of the equal distribution of prognostic indicators over the groups, possible selection and confounding bias are avoided. If the control group receives placebo intervention, the only extra intervention factor for the experimental group is the specific factor under study. Information bias is avoided by double-blinding, which means that neither the study population nor the persons who assess the effects of the assigned interventions know who is receiving the active and who the placebo intervention. In this way results will be internally valid.

A critical point in experiments, in humans as well as in animals, is the operationalization of the research question and the generalization of the results. In other words, the external validity poses more problems than the internal validity.

In chapter 2 the literature about vitamin A and cancer is reviewed, with an emphasis on epidemiological studies. Existing evidence suggests that beta-carotene is more likely to be responsible for the cancer preventive effect than retinol. However, any factor that is highly correlated with the intake of beta-carotene, and entails some biological plausibility, is a potential rival.

In order to gain more insight into the causality of the relation between beta-carotene and cancer, we performed a randomized experiment. We chose to study the effect of a supplemental dose of beta-carotene on the regression and progression rates of cervical dysplasia. About 300 women with cervical dysplasia participated in this experiment. They filled in a questionnaire inquiring about all presumed risk factors of cervical dysplasia, including sexual habits, smoking habits and a number of food habits. With respect to the latter, we inquired particularly about the consumption of foods containing beta-carotene, vitamin $C$, retinol or dietary fibre. We decided to mail the same questionnaire to a sample of the general population. This enabled us, with little extra effort, to perform a case-control study on the role of beta-carotene and other dietary factors in the etiology of cervical dysplasia. The results of this study are presented and discussed in chapter 3 .

Chapter 4 describes the design of the experiment, its rationale and implications. Special attention is paid to the critical choices we made in the operationalization. To get more insight into the question whether beta-carotene protects against cancer, we studied the influence of a supplemental dose of beta-carotene on cervical dysplasia.

In chapter 5 the results of this experiment are presented and discussed.

In the experiment we came across the problem of imprecisions in the interpretation of cervical biopsy specimens by different pathologists. We anticipated on this problem by having all histological slides revised by one pathologist. Nevertheless, we were interested in the interobserver variation between pathologists in grading cervical dysplasia. For this 
purpose, four pathologists were asked to score a sample of 106 slides which were used in our experiment. Chapter 6 presents the results of this interobserver study.

The epilogie (chapter 7) diseusses the contribution of epidemiological studies to the evidence for a causal relation between beta-carotene and cancer. Furthermore it will be related how the author's belief in the relation between beta-carotene and cancer was changed by the results of the studies we have performed. In addition, her expectations about future epidemiological studies are presented.

The most important parts of this thesis are briefly summarized in English in chapter 8 and more extensively in Dutch in chapter 9. 


\section{References}

1. Peto $R$, Doll $R$, Buckley JD, Sporn MB. Can dietary beta-carotene materially reduce human cancer rates? Nature 1981; 290: 201-208.

2. Rothman KJ. Modern Epidemiology. Boston, Toronto: Little, Brown and Company, 1986.

3. Block G. A review of validations of dietary assessment methods. Am J Epidemiol 1982; 115: 492-505. 


\section{Chapter 2}

\section{THE PUZZLING ROLE OF VTTAMIN A IN CANCER PREVENTION*}

Henrica C.W. de Vet

* Anticancer Research 1989; 9: 145-151 


\begin{abstract}
This review focuses on the question of whether the cancer preventive effect of dietary vitamin $\mathrm{A}$ should be attributed to retinol or to carotene. Knowledge about the metabolism of retinol and carotene and results from epidemiological studies point to an effect of carotene. Studies on the mechanisms of the vitamin A effect and results of experimental studies in animals lend, at the same time, much support to an effect exerted by retinol. Integration of data from experimental and epidemiological research leads to the conclusion that, in contrast to retinol, a high intake of carotene most likely influences cancer incidence in humans, either via an effect exerted by carotene itself or after conversion into retinol.
\end{abstract}


The relation between vitamin $\mathrm{A}$ and cancer has been extensively studied and reviewed $(1,2,3,4)$, but remains confusing. Since Peto et al $(5)$ suggested a possible protective role of beta-carotene in epidemiological studies, the effects of retinol and of carotene have been differentiated. This paper focuses on the question of which component of dietary vitamin $A$, retinol or carotene, causes the anticancer effect.

\section{Terminology}

Vitamin A consists of retinol and that part of some carotenoids that can be converted into retinol in the human body. There are other carotenoids which cannot be converted into retinol and thus have no vitamin $A$ activity. Of the convertible carotenoids, betacarotene is most efficiently converted into retinol. Because of its prevalence in many vegetables and fruits, it has been studied most extensively: Unfortunately, in the literature it is not always clearly stated whether all carotenoids, only the carotenoids that can be converted into retinol, or only beta-carotene is studied. In this paper the term carotenoids is used for the total group of carotenoids, the term beta-carotene is reserved for the situation in which only beta-carotene is studied and the term carotene is used if all convertible carotenoids are studied or in case it is not explicitly stated.

\section{The metabolism of vitamin $A$}

\section{The metabolism of retinol}

Retinol is present in animal products, such as liver, meat, eggs, and milk products. After absorption in the small intestine, retinol is transported as retinylester in chylomicrons to the liver, where it is stored. From the liver it is transported to the tissues through the blood, bound to a retinol binding protein. As retinol is relleased from the liver at essentially constant rates, the serum retinol level is hardly influenced by the intake of vitamin $A(6)$. In recent studies, a very small, although statistically significant, increase in serum retinol level was found after supplementation with doses of 3-7 times the recommended dietary allowance of retinol, especially in persons with a rather low vitamin $A$ intake or serum retinol levels $(7,8)$.

\section{The metabolism of the carotenoids}

Carotenoids mainly occur in vegetables and fruits. To calculate the vitamin A content of the food, $1 / 6$ of the carotenoid content is added to the retinol content. "This conversion factor makes allowance for the rather poor absorption of carotenoids in the small intestine and the inefficient conversion of carotenoids into retinol. About $70 \%$ of the absorbed carotenoids are converted into retinol (9) and the rest is transported in the lipopotein fraction of plasma and is taken up by adipose tissue and liver. The plasma level of carotenoids changes in direct relation to the recent intake of carotenoids (6), notwithstanding their incomplete absorption, partial conversion into retinol, and several sites of disposition. Thus the plasma level of carotenoids is diet-dependent, in contrast to the plasma level of retinol which is largely diet-independent except in the deficient state. 
These kinetic facts make it difficult to see a role for retinol in dietary influences on carcinogenesis.

\section{The effect of vitamin $A$, retinoids and carotenoids on cancer in experimental studies}

A well-known function of vitamin $\mathrm{A}$ is its role in maintaining the normal differentiation of epithelial tissues. Wolbach and Howe (10) observed that vitamin A deficiency induces profound changes in epithelial tissues: the mucosal lining of these tissues is replaced by a squamous metaplastic epithelium, a proces similar to that induced by chemical carcinogens (11). This observation stimulated research on retinol as an anticancer agent. The toxicity of high doses of retinol prompted the synthesis of retinol derivates (retinoids), which are less toxic and reach the post-hepatic tissues in higher quantities. The effects of these retinoids have been extensively studied in vivo and in vitro. Among these is retinoic acid, a natural metabolite of retinol.

From animal experiments there are convincing data on the preventive effect of many retinoids on carcinogen-induced cancer of the skin, breast, bladder, oesophagus, cervix and liver (cf. 1). However, in some studies retinoids stimulated tumor development (cf. 1). Animal experiments have clearly indicated that the cancer preventing effectiveness of a retinoid is dependent on the type of retinoid, the target tissue and the mechanism of tumor induction.

Clinical trials in humans also show promising effects of retinoids in cancer prevention (12), although there are still some problems with the toxicity of these agents.

Carotenoids are not as extensively studied as retinol and its analogues. UV-induced skin tumors are most often studied, against which carotenoids show a protective effect $(13,14)$.

\section{The presumed mechanisms of the effect of vitamin $A$ on cancer}

To find out whether the cancer preventive effect is exerted by retinol or by carotenoids, the knowledge about the mechanisms of the effects will be presented separately.

The presumed mechanisms of the retinol effect

Various explanations have been offered for the cancer preventing effect of retinol and its analogues (ct. 15,16,17).

It is presumed that the effect of retinol and the retinoids is exerted through an action on the cell nucleus, involving the expression of genetic information controlling cell differentiation (cf. 15,16,17). Specific binding proteins for retinol and retinoic acid are believed to be responsible for the transport of retinol or retinoic acid within the cell and across the nucleus membrane, suggesting a hormone-like control of cell differentiation.

In addition, however, retinol has a variety of effects on the cell membrane, involving altered glycoprotein synthesis and changes in membrane receptors for various hormones, including those mediated by c-AMP (cf. 15,16). The action on these 
receptors may influence cell-cell interactions, cell adhesion, and cell membrane permeability.

It has also been found that retinoids are able to antagonize some known tumor promoters, such as phorbolesters, which suggests a protective role of retinoids in the promotion stage of carcinogenesis (cf. 16).

Furthermore, animal studies have shown that retinol increases both the humoral and the cell-mediated immune response. The effect on the cell-mediated response is based on the induction of cytotoxic T-cells by retinol and its analogues (cf. 16).

The presumed mechanisms of the carotenoid effect

Carotenoids have antioxidant properties. Beta-carotene is a very efficient singlet-oxygen scavenger but is also able to inhibit lipid peroxidation (18). As it is supposed that free radicals may play a role in the etiology of cancer, carotenoids may protect against cancer by the antioxidant mechanism. There are no indications that carotenoids affect cell differentiation.

After reviewing the possible mechanisms of the anticancer effect of retinol and carotenoids, it is clear that both retinol and carotenoids are able, in theory, to play a role in the prevention against cancer. Thus the knowledge about the mechanisms of the effects does not favor either a retinol or a carotenoid effect.

\section{Differentiation between the effects of carotenoids and retinol}

\section{Laboratory experiments}

In animal experiments, both retinoids and carotenoids show cancer preventive effects (cf. 1,13).

Carotenoids could act in their own right or after conversion into retinol. To separate these effects, Mathews-Roth (19) studied the effect of carotenoids, with and without vitamin $A$ activity, on the occurrence of skin tumors in mice. The tumors were induced by UV-B irradiation, by $\operatorname{DMBA}(7,12)$-dimethylbenz(a)-anthracene and croton oil application, or by DMBA and UV-B irradiation. The carotenoids without vitamin A activity were most effective in inhibiting UV-B induced tumors, while vitamin A activity was necessary to inhibit tumors induced by DMBA and croton oil application. Stich et al (20) studied the effect of retinol, beta-carotene, and canthaxanthin, a carotenoid which cannot be converted into retinol, to prevent genotoxic damage in exfoliated human oral mucosa cells of betelnut chewers. They found that retinol and beta-carotene strongly reduced the number of cells with micronuclei, a marker for genotoxicity, while canthaxanthin had no effect.

Thus these studies show that for some anticancer effects conversion into retinol is required, while in other situations carotenoids without vitamin A activity exert a protective effect. Apparently two different mechanisms of cancer prevention are involved. 


\section{Epidemiological studies}

Many case-control studies and a few cohort studies have examined the effect of dietary vitamin A, retinol and/or carotene on several types of cancer. In table 1 the results of case-control studies in which the effects of carotene and/or retinol are studied separately are summarized, plus the results of prospective cohort studies on vitamin $A$, retinol, or carotene, and cancer.

Table 1: Observational epidemiological studies: differences ${ }^{1}$ between cases and controls, in the intake of vitamin $\mathrm{A}$, retinol and carotenes.

Case-control studies

cancer site, number of cases, male (m), remale (f) difference in the inlake of vitamin $A$ or $A$ andiex difference in the intake of retinoll difference in the intake of carotenes
Smith and Jick (21)

Modan et al (22)

Wyllie-Rosett et al (23)

Byers et al (24)

Marshail et al (25)

LaVecchia et al (26)

Hinds at al (27)

Winn ef al (28)

Risch et al (29)

Wu et al (30)

Kolonel et al (31)

Potter and McMichael (32)

Brock et al (33)

Ziegler et al (34)

Pisani et al (35) various sites $371 \mathrm{~m}+429 \mathrm{f}$ stomach + colon $406 \mathrm{~m}+\mathrm{f}$ cervixdysplasia $25 \mathrm{f}$

ovary

$274 f$

cervix

$513 \mathrm{f}$

cervix

191f

lung

$261 \mathrm{~m}+103 \mathrm{f}$

oral + pharyngeal

$227 \mathrm{f}$

stomach

$163 m+83 r$

lung 5

$210 \mathrm{f}$

bladder

$123 m+41 f$

prostate

$418 \mathrm{~m}$

colon + rectum

$419 \mathrm{~m}+\mathrm{f}$

cervixca in situ

$117 \mathrm{f}$

lung

$763 \mathrm{~m}$

lung

$386 m+31 f$ $\mathrm{m} \downarrow, \mathrm{f0}$

0

0

$\downarrow$

$0^{2}$

0

13

$0^{2}$

0

0

$m+, 0$

$\mathrm{m} \downarrow, 10$

$0^{4}$

a

0

-
$-\quad 06$

$\downarrow$

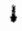

$\downarrow$ ns

47

$\uparrow \mathrm{ns}, 7$

0

0

0

0

0

0

$\downarrow$

0 
Case-control studies (continued)

\begin{tabular}{|c|c|c|c|}
\hline $\begin{array}{l}\text { cancer site, } \\
\text { number of cases, } \\
\text { male (m), } \\
\text { female if }\end{array}$ & $\begin{array}{l}\text { difference in } \\
\text { the intake of } \\
\text { witamin } A\end{array}$ & $\begin{array}{l}\text { difference in } \\
\text { the intake of } \\
\text { retinol }\end{array}$ & $\begin{array}{l}\text { difference in } \\
\text { the intake of } \\
\text { carotenes }\end{array}$ \\
\hline
\end{tabular}

Byers et al (36)

La Vecchia et all (37)

lung

$296 m+154 f$

ovary

$413 f$

Humble et al (38)

lung

Bond et al (39)

$312 \mathrm{~m}+155 \mathrm{f}$

lung

$308 \mathrm{~m}$.

Pastorino et al (40)

lung

$47 \mathrm{f}$

Marubini et al (41)

breast

$214 \mathrm{f}$

Katsouyanni et al (42)

breast

$120 \mathrm{f}$

$\begin{array}{ccc}\mathrm{m} \downarrow, \mathrm{f} \downarrow \mathrm{ns} & 0 & \mathrm{~m} \downarrow, \mathrm{f} \downarrow \mathrm{ns} \\ + & 0 & \downarrow \\ \downarrow & 0 & \downarrow \\ - & 0 & \downarrow \\ - & \downarrow \mathrm{ns} & 0 \\ \downarrow & 0 & \downarrow\end{array}$

Cohort studies

\begin{tabular}{|c|c|c|c|c|}
\hline Bjelke (43) & $\begin{array}{l}\text { lung } \\
36 \mathrm{~mm}\end{array}$ & $\Downarrow$ & - & - \\
\hline \multirow[t]{2}{*}{ Hirayama (44) } & lung & - & - & 19 \\
\hline & $\begin{array}{l}611 \mathrm{~m}+149 \mathrm{f} \\
\text { prostate } \\
63 \mathrm{~m}\end{array}$ & - & - & 19 \\
\hline \multirow[t]{2}{*}{ Shekelle et al (45) } & $\begin{array}{l}\text { lung } \\
33 \mathrm{~m}\end{array}$ & - & 0 & 4 \\
\hline & $\begin{array}{l}\text { other sites } \\
173 \mathrm{~m}\end{array}$ & - & 0 & 0 \\
\hline Kvăle et al (46) & $\begin{array}{l}\text { lung } \\
144 m+9 f\end{array}$ & $\downarrow 10,11$ & $*$ & . \\
\hline Colditz et al (47) & $\begin{array}{l}\text { all sites } \\
42 m+f\end{array}$ & . & - & 1 \\
\hline Paganini-Hill et al (48) & $\begin{array}{l}\text { all sites } \\
435 m+f\end{array}$ & - & - & $0^{12}$ \\
\hline
\end{tabular}

Legend: $1 .-=$ not studied or not presented; $0=$ no difference; $1=$ the cases have a statistically significantly lower intake than the controls; $\uparrow=$ the cases have a statistically significantly higher intake than the controls; $n$ s = not statistically significant; 2 . The vitamin $A$ index is based on the consumption of vegetables and fruits, milk, chicken and meat; 3 . Only for women $30-49$ years of age; 4 . The intake of retinol is based on eggs and dairy products; 5 . Squamous lung cancer and adenocarcinoma; 6 . Total retinol intake had no effect, an effect was found for dairy products and eggs together; 7 . Only for men > 70 years of age; 8 . The effect is statistically significant for carrots, not for green leafy vegetables; 9.

Yellow-green vegetables based on the level of beta-carotene in the vegetables; 10 . Only for squamous and small cell lung cancer; 11 . The vitamin $A$ index is based on vegetables, milk and eggs; 12. The intake of beta-carotene is based on the frequency of carrot consumption. 
In almost all studies an inverse relation between the intake of carotene and cancer was found, while almost none of the studies showed a relation with the retinol intake. The intake of retinol and carotene combined, either measured as the total vitamin $A$ intake or as a vitamin $A$ index, if the intake was based on only a few vitamin $A$ sources, showed inconsistent results. These studies clearly show that carotene is very consistent in exerting the cancer preventive effect, while retinoll intake is not associated with cancer prevention. This result is in accordance with knowledge about the metabolism of vitamin A. Carotene reaches the peripheral tissues while retinol is largely stored in the liwer. Should we then conclude that, in humans, carotene is uniquely responsible for the protective effect against cancer?

\section{Arguments that favor a retinol effect}

While the epidemiological studies and the metabolic facts clearly point to a carotene effect, there are some arguments to suggest that the effect is exerted by retinol. Firstly, there is much evidence for a retinol effect from laboratory experiments with retinoids; secondly, the observations of Mathews-Roth (19) and Stich et al (20) show that in some situations a carotenoid needs vitamin $A$ activity to exert an anticancer effect. This implies that it depends on the way of cancer induction via which mechanism the process can be inhibited or prevented. Thirdly, the epidemiological studies indirectly give indications for a retinol effect. To explain the latter argument further, we must take a closer look at the cancer sites for which the protective effect is observed.

\section{The specificity of the effect for epithelial tissues and specific histological subtypes}

\section{Epidemiological studies}

Apparent protective effects of vitamin A or beta-carotene have been found most consistently and most strongly for cancers in which squamous cell histological types predominate, such as oral (49), oesophageal (50), laryngeal (51), lung , and cervical cancer (table 1). In contrast, the effects of vitamin A or carotene have been inconsistent for cancer of the stomach, colon and rectum, breast, ovary, and prostate (table 1), where adenocarcinoma is the predominant histological type. Although associtations have been observed for breast cancer (52) and cancer of the ovary (24), they are generally weak and seen only in certain age groups. In prostatic cancer, a site with adenocarcinomas, the relation between vitamin $A$ or carotene and cancer risk was actually reversed in three out of four studies $(31,53,54)$, a seeming qualitative difference that needs careful further study.

In some studies the effect of vitamin $\mathbf{A}$ on different histological subtypes of lung cancer was assessed. Three studies $(34,46,55)$ found that the protective effect of vitamin $A$ or carotene was not apparent in adenocarcinoma, whereas in one study (30) a protective effect of carotene intake was observed on both adenocarcinoma and squamous cell lung cancer in women. Another study (36) found the strongest protective effect in the 
squamous cell subgroup, with a weaker effect in the adenocarcinoma subgroup and almost no effect in the small cell subgroup.

The observation that vitamin A or carotene is protective against squamous cell cancers is consistent with the well-known function of retinol in the maintenance of normal differentiation of the epithelium. Thus this strongly points to a retinol mediated effect. Having presented epidemiological evidence for the effect of vitamin $A$ or carotene on epithelial tissues, specifically for the squamous cell type of cancer, we turn back to the animal experiments and in vitro studies to see whether a similar specificity for these tissues is found.

\section{Laboratory experiments}

In experimental studies, the effect of retinol and retinoids is not specific for epithelial cancers, as effects are observed in various kinds of tissues, e.g. mesenchymal cells, in which retinoids are able to influence the cell differentiation and to affect the cell surface (56). Embryonal carcinoma cell lines have also been studied and retinoids have been found to influence differentiation into endodermal and fibroblastic cells. It has been shown that in these cells the activity of the retinoids varies with the presence of cellular retinol and retinoic acid binding proteins (57). Thus the mechanisms described for retinol are not limited to the epithelial tissues. Moreover, the specificity for specific histological subtypes is not observed in animal experiments (cf. 1). In several studies an effect of retinoids on mammary tumors is reported, a cancer site in which adenocarcinomas predominate. In the case of bladder cancer an effect was observed on squamous cell carcinomas, but also on transitional cell carcinomas and papillomas. How then can the specificity for epithelial cells in epidemiological studies be explained? It should be remarked that the literature shows a certain selection bias: the effect on epithelial tissues is the most extensively studied, as the evident motivation to study the effect of vitamin A was its early recognized function in the differentiation of epithelial tissues. Consequently there are hardly any epidemiological data on the effect of vitamin A on non-epithelial tissues. Yet the specificity for squamous cell cancers in the epidemiological studies is striking. A possible explanation for this specificity is that squamous epithelial tissues have a much higher rate of cell division than glandular and other cells. Therefore an effect of vitamin $A$ on these fast dividing tissues may be more readily visible and thus more pronounced than on adenocarcinomas. However, this still does not explain the difference between human and animal studies in preference for squamous cell carcinomas.

\section{Which component of vitamin A exerts the ultimate effect}

Turning back to our primer question as to whether the effect is exerted by retinol or by carotene, the knowledge that the intake of carotene and not of retinol is associated with the cancer preventive effect still leaves room for two possibilities: either the effect is exerted by carotene itself or after conversion into retinol. The first possibility implies that human cancer develops by a mechanism which is inhibited or prevented by 
carotene. The second possibility implies that carotene is converted into retinol in posthepatic tissues, to evade the storage of retinol in the liver. This subject deserves further attention.

\section{The conversion of carotene into retinol}

The conversion of carotene into retinol largely occurs pre-hepatically, primarily in the intestinal mucosa, and to a lesser extent in the liver itself (cf. 15). However, from various animal studies it is apparent that a number of post-hepatical tissues may be able to convert carotene into retinol. Bieri and Pollard (58) demonstrated that conversion of intravenously administered beta-carotene into retinol was unaffected by the removal of the small intestine, the normal site of conversion after oral administration. The same authors noted that in nephrectomized rats, and in rats from which up to $75 \%$ of the liver tissue had been removed, the amounts of retinol formed after injection were similar to the amounts formed in intact control rats. It was also demonstrated that complete removal of the liver $(59,60)$, stomach, small intestine, large intestine, spleen, pancreas, kidneys, adrenals, or gonads (60), or complete removal of all lung tissue (61) in no way affected the conversion into retinol. Although these studies were carried out a long time ago, they have not been contradicted subsequently. However, it is advisable to replicate these studies using modern methods. From these early studies it can be concluded that many tissues probably possess the ability to convert carotene into retinol. Thus there is no need to reject the hypothesis that carotene exerts its effect after conversion into retinol. On the contrary, it is a very attractive theory because it fits all the existing data on carotene and retinol in relation to cancer.

\section{Conclusion}

Epidemiological studies show a protective effect of a high intake of carotene on cancer, and no effect of retinol: This is in accordance with the knowledge about the metabolism of retinol and carotene: a high intake of retinol does not result in a high serum level, as retinol is stored in the liver. In contrast, the intake of carotenoids is reflected in the serum level of carotenoids and is therefore much more likely to exert a cancer preventive effect in peripheral tissues.

Regarding the mechanism of the cancer preventive effect, several possibilities have been postulated. Carotenoids are known antioxidants and retinoids are supposed to be able to influence carcinogenesis in various ways. It is noteworthy that retinol and its derivates are effective in preventing tumors in experimental animals, while retinol does not show any effect in epidemiological studies. However, experiments with retinoids which escape storage in the liver, do show promising results on human cancer. Thus the metabolic fate of retinol, being storage in the liver, precludes an effect of dietary retinol. Apparently the slight increase in serum retinol levels associated with a high intake of retinol does not lead to a cancer preventive effect. 
Based on current knowledge, dietary carotene seems most likely responsible for the cancer preventive effect. Whether it is only effective after conversion into retinol, or as carotene as such, or via both mechanisms, is not clear. Further study is needed on this subject, especially on the hypothesis that the conversion occurs post-hepatically.

At this moment, from in vitro and in vivo studies and from experimental and observational epidemiological research, there are many pieces of evidence for an effect of vitamin $\mathrm{A}$ and related components in cancer prevention. It is a challenging task for the future to fit these small pieces into a complete picture of the cancer preventive process. 


\section{References}

1. Hill DL, Grubbs CJ. Retinoids as chemopreventive and anticancer agents in intact animals (review). Anticancer Res 1982; 2: 111-124.

2. Mettlin C. Epidemiologic studies on vitamin A and cancer. Adv Nutr Res 1984; 6: $47-65$.

3. Ong DE, Chytil F. Vitamin A and cancer. Vitam Horm 1983; 40: 105-132.

4. Bollag W, Hartmann HR. Prevention and therapy of cancer with retinoids in animals and man. Cancer Surv 1983; 2: 293-314.

5. Peto R, Doll R, Buckley JD, Sporn MB. Can dietary beta-carotene materially reduce human cancer rates? Nature 1981; 290: 201-208.

6. Willett WC, Stampfer MJ, Underwood BA, Taylor JO, Hennekens CH. Vitamin A, E and carotene: effects of supplementation on their plasma levels. Am J Clin Nutr 1983; 38: 559-566.

7. Willett WC, Stampfer MJ, Underwood BA, et al. Vitamin A supplementation and plasma retinol levels: a randomized trial among women. J Natl Cancer Inst 1984; 73: $1445-1448$.

8. Wald NJ, Cuckle HS, Barlow RD, et all. The effect of vitamin A supplementation on serum retinol and retinol binding protein levels. Cancer Lett 1985; 29: 203-213.

9. Goodman DS, Blomstrand R, Werner B, Huang HS, Shiratori T. The intestinal absorption and metabolism of vitamin $\mathrm{A}$ and beta-carotene in man. J Clin Invest 1966; 45: 1615-1623.

10. Wolbach $\mathrm{SB}$, Howe PR. Tissue changes following deprivation of fat soluble $\mathrm{A}$ vitamin. J Exp Med 1925; 42: 753-777.

11. Lasnitzki I. Hypovitaminosis-A in the mouse prostate gland cultured in chemically defined medium. Exp Cell Res 1962; 28: 40-51.

12. DeWys WD, Malone WF, Burtrum RR, Sestili MA. Clinical trials in cancer prevention. Cancer 1986; 58: 1954-1962.

13. Epstein $\mathrm{JH}$. Effects of beta-carotene on ultraviolet induced cancer formation in the hairless mouse skin. Photochem Photobiol 1977; 25: 211-213.

14. Mathews-Roth MM. Carotenoid pigment administration and delay in development of UV-B induced tumors. Photochem Photobiol 1983; 37: 509-511.

15. Wolf G. Multiple functions of vitamin A. Physiol Rev 1984; 64: 873-937.

16. Lotan R. Effects of vitamin $A$ and its analogs (retinoids) on normal and neoplastic cells. Biochim Biophys Acta 1980; 605: 33-91.

17. Sporn $M B$, Roberts $A B$. Role of retinoids in differentiation and carcinogenesis. Cancer Res 1983; 43; 3034-3040.

18. Burton GW, Ingold KU. Beta-carotene: an unusual type of lipid antioxidant. Science 1984; 224: 569-573.

19. Mathews-Roth MM. Antitumor activity of beta-carotene, canthaxanthin and phytoene. Oncology 1982; 39: 33-37. 


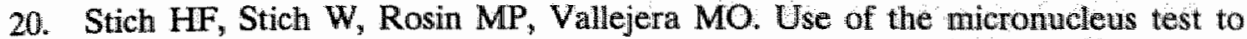
monitor the effect of vitamin $A$, beta-carotene and canthaxanthin on the buccal mucosa of betelinut/tobacco chewers. Int J Cancer 1984; 34: 745-750.

21. Smith $\mathbf{P G}$, Jick $\mathbb{H}$. Cancers among users of preparations containing vitamin $A$. $A$ case-control investigation. Cancer 1978; 42: 808-811.

22. Modan B, Cuckle H, Lubin F. A note on the role of dietary retinol and carotene in human gastro-intestinal cancer. Int $\mathrm{J}$ Cancer 1981; 28: 421-424.

23. Wylie-Rosett JA, Romney SL, Slagle NS, et al. Influence of vitamin A on cervical dysplasia and carcinoma in situ. Nutr Cancer 1984; 6: 49-57.

24. Byers T, Marshall J, Graham S, Mettlin C, Swanson M. A case-control study of dietary and non-dietary factors in ovarian cancer. J Natll Cancer Inst 1983; 71 : 681-686.

25. Marshall JR, Graham S, Byers T, Swanson M, Brasure J. Diet and smoking in the epidemiology of cancer of the cervix. J Natl Cancer Inst 1983; 70: 847-851.

26. LaVecchia $C$, Franceschi $S$, Decarli $A$, et al. Dietary vitamin $A$ and the risk of invasive cervical cancer. Int J Cancer 1984; 34: 319-322.

27. Hinds MW, Kolonel LN, Hankin JH, Lee J. Dietary vitamin A, carotene, vitamin $\mathrm{C}$ and risk of lung cancer in Hawaii. Am J Epidemiol 1984; 119: 227-237.

28. Winn DM, Ziegler RG, Pickle LW, Gridley G, Blot WJ, Hoover RN. Diet in the etiology of oral and pharyngeal cancer among women from the Southern United States. Cancer Res 1984; 44: 1216-1222.

29. Risch HA, Jain $M$, Choi $N W$, et al. Dietary factors and the incidence of cancer of the stomach. Am J Epidemiol 1985; 122: 947-959.

30. Wu $\mathrm{AH}$, Henderson BE, Pike MC, Yu MC. Smoking and other risk factors for lung cancer in women. J Natl Cancer Inst 1985; 74: 747-751.

31. Kolonel LN, Hinds MW, Nomura AMY, Hankin JH, Lee J. Relationship of dietary vitamin $A$ and ascorbic acid intake to the risk of cancers of the lung, bladder, and prostate in Hawaii. Natl. Cancer Inst Monogr 1985; 69: 137-142.

32. Potter JD, McMichael AJ. Diet and cancer of the colon and rectum: a case-control study. J Natl Cancer Inst 1986; 76:557-569.

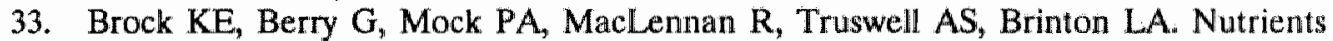
in diet and plasma and risk of in situ cervical cancer. J Natl Cancer Inst 1988; 80* 580-585.

34. Ziegler RG, Mason TJ, Stemhagen A, et al. Carotenoid intake, vegetables, and the risk of lung cancer among white men in New Jersey. Am J Epidemiol 1986; 123: 1080-1093.

35. Pisani $\mathbf{P}$, Berrino $F$, Macaluso $\mathbf{M}$, Pastorino U, Crosignani $\mathbf{P}$, Baldasseroni A. Carrots, green vegetables and lung cancer: a case-control study. Int $J$ Epidemiol 1986; 15: 463-468.

36. Byers TE, Graham $S$, Haughey BP, Marshall JR, Swanson M. Diet and lung cancer risk: findings from the western New York diet study. Am J Epidemiol 1987; 125: $351-363$. 
37. La Vecchia $C$, Decarli $A$, Negri $E$, et al. Dietary factors and the risk of epithelial owarian cancer. J Natl Cancer Inst 1987; 79: 663-669.

38. Humble CG, Samet JM, Skipper BE. Use of quantified and frequency indices of vitamin A intake in a case-control study of lung cancer. Int J Epidemiol 1987; 16: 341-346.

39. Bond GG, Thompson FE, Cook RR. Dietary vitamin A and lung cancer: results of a case-control study among chemical workers. Nutr Cancer 1987; 9: 109-121.

40. Pastorino U, Pisaní $P$, Berrino $F$, et al. Vitamin $A$ and female lung cancer: a case-control study on plasma and diet. Nutr Cancer 1987; 10: 171-179.

41. Marubini $E$, Decarli $A$, Costa $A$, et al. The relationship of dietary intake and serum levels of retinol and beta-carotene with breast cancer. Results of a case-control study. Cancer 1988; 61: 173-180.

42. Katsouyanni $\mathrm{K}$, Willett $\mathrm{W}$, Trichopoulos $\mathrm{D}$, et al. Risk of breast cancer among Greek women in relation to nutrient intake. Cancer 1988; 61: 181-185.

43. Bjelke E. Dietary vitamin A and human lung cancer. Int J Cancer 1975; 15: 561-565.

44. Hirayama T. Diet and cancer. Nutr Cancer 1979; 1: 67-81.

45. Shekelle RB, Liu S, Raynor WJ, et al. Dietary vitamin A and risk of cancer in the Western Electric Study. Lancet 1981; ii: 1185-1190.

46. Kvåle G, Bjelke E, Gart JJ. Dietary habits and lung cancer risk. Int J Cancer 1983; 31: 397-405.

47. Colditz GA, Branch LG, Lipnick RJ et al. Increased green and yellow vegetable intake and lowered cancer death in an elderly population. Am J Clin Nutr 1985; 41: 32-36.

48. Paganini-Hill A, Chao A, Ross RK, Henderson BE. Vitamin A, beta-carotene and the risk of cancer: a prospective study. J Natl Cancer Inst 1987; 79: 443-448.

49. Marshall J, Graham S, Mettlin C, Shedd D, Swanson M. Diet in the epidemiology of oral cancer. Nutr. Cancer 1982; 3: 145-149.

50. Mettlin C, Graham S, Priore R, Marshall J, Swanson M. Diet and cancer of the esophagus. Nutr Cancer 1981; 2: 143-147.

51. Graham S, Mettlin C, Marshall J, Priore R, Rzepka T, Shedd D. Dietary factors in the epidemiology of cancer of the larynx. Am J Epidemiol 1981; 113: 675-680.

52. Graham S, Marshall J, Mettlin C, Rzepka T, Nemoto T, Byers T. Diet in the epidemiology of breast cancer. Am J Epidemiol 1982; 116: 68-75.

53. Graham S, Haughey B, Marshall J, et al. Diet in the epidemiology of carcinoma of the prostate gland. J Natl Cancer Inst 1983; 70: 687-692.

54. Heshmat MY, Kaul L, Kovi J, et al. Nutrition and prostate cancer: a case-control study. The prostate 1985; 6: 7-17.

55. Byers T, Vena J, Mettlin C, Swanson M, Graham S. Dietary vitamin A and lung cancer risk: an analysis by histologic subtypes. Am J Epidemiol 1984; 120: 769-776.

56. Merriman RL, Bertram JS. Reversible inhibition by retinoids of 3-methylcholanthrene-induced neoplastic transformation in C3H/10T1/2 CL8 cells. Cancer Res 1979; 39: 1661-1666. 
57. Jetten AM, Jetten MER. Possible role of retinoic acid binding protein in retinoid stimulation of embryonal carcinoma cell differentiation. Nature 1979; 278: 180-182.

58. Bieri JG, Pollard CJ. Studies on the site of conversion of beta-carotene injected intravenously into rats. $\mathrm{Br} J$ Nutr $1954 ; 8: 32-44$.

59. McGillivray WA, Thompson SY, Worker NA. Further studies on the metabolism by rats of intravenously administered aqueous dispersions of carotenoid pigments. Br J Nutr 1956; 10: 126-134.

60. Worker NA. The effect of complete hepatectomy on the utilization by rats and rabbits of intravenously administered aqueous dispersions of carotene. $\mathrm{Br} J$ Nutr 1956; 10: 169-175.

61. Worker NA. Site of conversion of carotene into vitamin $A$ in the rat: further studies on aqueous dispersions administered intravenously. $\mathrm{Br} \mathrm{J}$ Nutr 1957; 11: 44-47. 

Chapter 3

THE ROLE OF BETA-CAROTENE AND OTHER DIETARY FACTORS IN THE ETIOLOGY OF CERVICAL DYSPLASIA: A CASE-CONTROL STUDY*

Henrica C.W. de Vet ${ }^{1}$, Paul G. Knipschild ${ }^{1}$,

Marjolein E.C. Grol ${ }^{1}$, Hubert J.A. Schouten ${ }^{2}$, Ferd Sturmans ${ }^{1}$

1 Department of Epidemiology/Health Care Research

2 Department of Medical Informatics and Statistics, University of Limburg, Maastricht, the Netherlands

* Submitted for publication 


\begin{abstract}
The effects of beta-carotene and several other dietary factors on the risk of cervical dysplasia were evaluated in a case-control study. Cases $(n=257)$ were the participants of a randomized trial assessing the effect of beta-carotene on cervical dysplasia. Controls $(n=705)$ were sampled from the general population. A postal questionnaire was used to obtain information about the frequency of consumption of several food items containing beta-carotene, retinol, vitamin $\mathrm{C}$ and dietary fibre. Information was also collected about other risk factors for cervical dysplasia, in order to adjust for possible confounding. To our surprise, we observed an increased risk of cervical dysplasia for women with a high intake of beta-carotene $(\mathrm{OR}=2.31 ; 95 \% \mathrm{CI}: 1.27-4.19)$. No relation was found with the intake of retinol, while both vitamin $\mathrm{C}$ and dietary fibre showed a weak and not statistically significant inverse relation with cervical dysplasia. These findings do not support the hypothesis that beta-carotene protects against cervical dysplasia.
\end{abstract}




\section{Introduction}

In numerous epidemiological studies an inverse relation has been observed between the dietary intake of vitamin $A$ and the incidence of various types of cancer $(1,2,3,4)$. Dietary vitamin A consists of retinol and that part of some carotenoids that can be converted into retinol in the human body. All these convertible carotenoids will here be named after its most important representative: beta-carotene. A closer look at the epidemiological studies shows that beta-carotene is more likely to be responsible for the protective effect against cancer than retinol $(1,3,4)$. But it is quite possible that one or more other factors strongly associated with the intake of beta-carotene are responsible for the anticancer effect.

We performed a case-control study to assess the effect of the dietary intake of betacarotene on cervical dysplasia, a precursor of cervical cancer. In this study special attention was paid to the adjustment of unequal distributions of many other risk factors for cervical cancer. In addition to sexual and smoking habits, we also adjusted for the dietary intake of retinol, vitamin $C$ and dietary fibre. This enabled us to study the role of these nutrients in the etiology of cervical dysplasia at the same time.

\section{Methods}

\section{Cases}

Cases were participants of a multicenter trial in which the effect of a supplemental dose of $10 \mathrm{mg}$ beta-carotene on the regression rate of cervical dysplasia was assessed. Cases were entered during the years 1984-1987. Entry criteria were a histological diagnosis of cervical dysplasia and age 20-65 years. Excluded were patients who were pregnant or had diabetes mellitus or a severe liver or bowel dysfunction. The cases received a questionnaire two months after entry in the trial. This questionnaire inquired about the most important risk factors for cervical dysplasia in order to check whether the randomization had succeeded. It was this information which was used in the present case-control study. Of the 304 patients who satisfied the entry criteria of the trial and who received a questionnaire, 257 patients $(85 \%)$ returned it.

\section{Controls}

To obtain a control group we asked six municipalities to draw a sample of the female population from their population registers. We chose the three cities where most of the cases lived and one neighbouring village for each of these cities. In order to take seasonal variations in food consumption into account some people in the control group were approached in May 1987, others in August 1987 and the rest in January 1988. In each period a sample of 75 women was drawn from each city and a sample of 50 women from each village. This resulted in a totall number of 1125 women in the control group. We applied frequency matching for age with a proportional distribution over the age categories $20-29,30-39$ and $40+$ of, respectively, $40 \%, 40 \%$ and $20 \%$. 
Of the 1125 questionnaires mailed, 14 turned out to be undeliverable. After two reminders $747(67 \%)$ women had returned their questionnaire. Of these, 28 women reported that they were pregnant, 3 had diabetes mellitus, 8 had a severe bowel or liver dysfunction and 3 women had undergone laysterectomy. These controls were excluded to match the entry criteria for the cases. This resulted in 705 controls. Of these, 46 women reported that they had had an abnormal smear in their medical history. They were kept in the control group in the main analysis, but an additional analysis was performed dealing with these 46 women as a separate group of cases.

\section{Questionnaire}

Cases and controls received the same postal questionnaire, which inquired about demographic characteristics, marital status, level of education, number of children, use of contraceptives, age at first sexual intercourse, frequency of intercourse, number of sexual partners and abnormal smears, as well as about their habitual frequency of consumption of various food items. Because we were especially interested in betacarotene, five groups of vegetables were distinguished on the basis of their betacarotene content: carrots, spinach, kale, other cabbages and pulses. We asked about the frequency of consumption of vegetables from these five groups in the preceding month, and whether the portion size was usually small, medium or large. The questionnaire further inquired about the consumption of fruits, especially citrus fruits and apples, and of orange juice and tomatoes, in order to assess the intake of vitamin C. Moreover, the major sources of retinol, such as dairy products, eggs, liver and vitamin A fortified margarin were included, as well as the use of vitamin $\mathrm{A}$ and $\mathrm{C}$ containing pills. To estimate the intake of dietary fibre, the consumption of bread was assessed in addition to vegetables and fruits. The decision to include a specific food item in the questionnaire was based on its contribution to the total intake of a specific nutrient. We obtained these data from a food survey in a pilot study for a prospective cohort study on nutrition and cancer in the Netherlands (5).

On the basis of these questions, indices for the average daily intake of beta-carotene, retinol, vitamin $C$ and dietary fibre were calculated, using the average nutrient content of the foods (6) multiplied by portion size. We arbitrarily decided that a small portion size corresponded to $150 \mathrm{~g}$, a medium portion size to $250 \mathrm{~g}$, and a large portion size to $350 \mathrm{~g}$. The beta-carotene index included all carotenoids that are convertible into retinol. Since our questionnaire did not cover all possible sources of dietary beta-carotene, retinol, vitamin $\mathrm{C}$ and dietary fibre, the computed indices should be interpreted as relative estimates of intake. However, as they corresponded fairly well with the known mean intake of these nutrients in the Netherlands (7) the indices are nevertheless expressed in mgs or gs.

In the analysis, we adjusted for the date of filling in the questionnaire by using a trichotomous variable corresponding to the three periods of sampling of the control group: January-April, May-July, August-December. The cases group received their questionnaires at various dates during the year. Adjustment for this variable also controlled seasonal variations in nutrient contents of certain foods. 


\section{Statistical analysis}

The indices of beta-carotene and the other nutrients were categorized into four classes. The cut-off points were chosen at whole or half gs or mgs, in such a manner that the study population was fairly equally distributed over the classes. For food items the cutoff points were chosen in such a way that each class contained a reasonable number of women. For each of these classes crude odds ratios (ORs) were calculated with testbased $95 \%$ confidence intervals, using the class with the lowest intake as the reference category. In addition, tests for trend were performed (8).

In a logistic regression model we adjusted for all confounding factors simultaneously. All potential confounding factors were included in the model as categorical variables using indicator terms (9). When studying the effect of a nutrient index, the risk factors adjusted for included the indices for the other nutrients. When studying the effect of food items, the factors adjusted for included other food items. The coefficients in the logistic regression model were used to calculate adjusted ORs with their 95\% precisionbased confidence intervals (9). Additionally, tests for trend were performed by assigning a score to each class of the variable and then treating it as a continuous variable in the regression model (9). BMDP software was used for all statistical analyses (10).

\section{Results}

In all, 257 cases and 705 controls provided data for the analyses. Failure of some respondents to answer particular questions resulted in some missing values for certain variables.

Table 1 shows the distribution of dietary intake of beta-carotene for cases and controls. The crude ORs fluctuated around 1.0, indicating no association between the dietary intake of beta-carotene and the risk for cervical dysplasia. The average daily intake of beta-carotene for the cases was $2.81 \mathrm{mgs}$, compared to $2.68 \mathrm{mgs}$ for the controls. Seasonal fluctuations were small. We adjusted for all relevant confounding factors simultaneously in a logistic regression model. This changed the crude ORs in such a way that the classes with the highest dietary intake of beta-carotene had a statistically significantly higher risk for cervical dyplasia than the class with the lowest intake. For an intake of less than $1.5 \mathrm{mg}$ compared to more than $3.5 \mathrm{mg}$ of beta-carotene: $\mathrm{OR}=$ 2.31 (95\% CI: $1.27-4.19$ ). 
Table 1: Dietary intake of beta-carotene in cases and controls, crude and adjusted odds ratios and $95 \%$ confidence interwals (C).

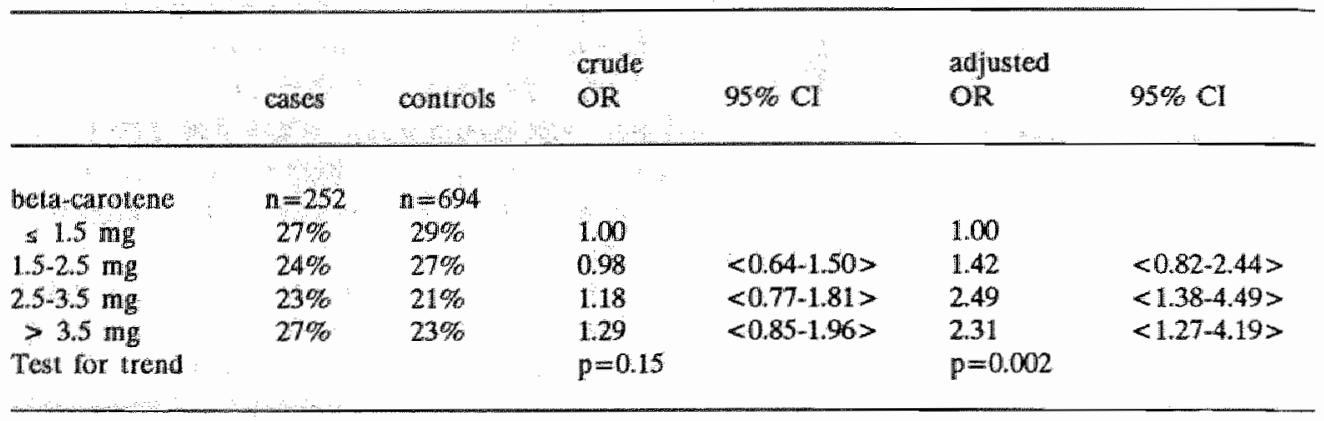

We performed similar analyses for the intake of retinoll, vitamin $\mathrm{C}$ and dietary fibre. Table 2 shows that the women in the second and third quartile of retinol intake showed the highest risk. For both vitamin $\mathrm{C}$ and dietary fibre a weak inverse relation was observed between the dietary intake and risk for cervical dysplasia. After adjustment for relevant confounding factors the inverse relations remained, but did not reach statistical significance. The data on the use of vitamin $A$ and $C$ pills were in keeping with these observations. The relation with the use of vitamin $\mathrm{A}$ appeared to be inconsistent, while vitamin $\mathrm{C}$ pills showed a weak inverse relation with the risk of cervical dysplasia.

Table 2: Dietary intake of retinol, vitamin $\mathrm{C}$ and dietary fibre and use of vitamin $\mathrm{A}$ and vitamin $\mathrm{C}$ containing pills in cases and controls: crude and adjusted odds ratios and $95 \%$ confidence intervals (CI).

\begin{tabular}{|c|c|c|c|c|c|c|}
\hline & cases & controls & $\begin{array}{l}\text { crude } \\
\text { OR }\end{array}$ & $95 \% \mathrm{Cl}$ & $\begin{array}{l}\text { adjusted } \\
\text { OR }\end{array}$ & $95 \% \mathrm{CI}$ \\
\hline retinol & $n=254$ & $n \equiv 696$ & & & & \\
\hline$\div 0.3 \mathrm{mg}$ & $26 \%$ & $31 \%$ & 1.00 & & 1.00 & \\
\hline $0.3-0.4 \mathrm{mg}$ & $25 \%$ & $20 \%$ & 1.53 & $\langle 1.00-234\rangle$ & 1.37 & $<0.81-2.33\rangle$ \\
\hline $0.4-0.5 \mathrm{mg}$ & $19 \%$ & $16 \%$ & 1.46 & $\langle 0.93 \mathrm{~m} .31\rangle$ & 1.68 & $<0.95-2.99>$ \\
\hline $\begin{array}{l}>0.5 \mathrm{mg} \\
\text { Test for trend }\end{array}$ & $29 \%$ & $33 \%$ & $\begin{array}{l}1.03 \\
p=0.99\end{array}$ & $<0.70-154>$ & $\begin{array}{l}0.79 \\
p=0.38\end{array}$ & $<0.48-1.30\rangle>$ \\
\hline vilamin $\mathrm{C}$ & $\mathrm{n}=252$ & $\mathrm{n}=692$ & & & & \\
\hline$s 50 \mathrm{mg}$ & $27 \%$ & $24 \%$ & 1.00 & & 1.00 & \\
\hline $50.75 \mathrm{mg}$ & $21 \%$ & $17 \%$ & 1.12 & $\langle 0.71 \times 1.77\rangle$ & 0.88 & $\langle 0.49-1.57\rangle$ \\
\hline $75-100 \mathrm{mg}$ & $18 \%$ & $19 \%$ & 0.87 & $<0.55-1.39\rangle$ & 0.92 & $<0.50-1.68\rangle$ \\
\hline $\begin{array}{l}>100 \mathrm{mg} \\
\text { Test for trend }\end{array}$ & $35 \%$ & $40 \%$ & $\begin{array}{l}0.79 \\
p=0.12\end{array}$ & $<0.54-1.17\rangle$ & $\begin{array}{l}0.67 \\
p=0.17\end{array}$ & $\langle 0.39-1.16\rangle$ \\
\hline
\end{tabular}




\begin{tabular}{|c|c|c|c|c|}
\hline & & crude & & adjusted \\
\hline $\operatorname{cas}$ & cor & OR & $95 \% \mathrm{CI}$ & \\
\hline
\end{tabular}

\begin{tabular}{|c|c|c|c|c|c|c|}
\hline dietary fibre & $n=243$ & $\mathrm{n}=694$ & & & & \\
\hline$\leq 10 \mathrm{~g}$ & $22 \%$ & $17 \%$ & 1.00 & & 11.00 & \\
\hline $10-15 \mathrm{~g}$ & $33 \%$ & $35 \%$ & 0.69 & $\langle 0.45-1.07\rangle$ & 0.72 & $\langle 0.41-1.27\rangle$ \\
\hline $15-20 \mathrm{~g}$ & $30 \%$ & $29 \%$ & 0.78 & $\langle 0.50-1.21\rangle$ & 0.65 & $<0.35-1.22>$ \\
\hline$>20 \mathrm{~g}$ & $15 \%$ & $19 \%$ & 0.61 & $\langle 0.36-1.02\rangle$ & 0.64 & $<0.31-1.30\rangle$ \\
\hline Test for trend & & & $p=0.11$ & & $\mathrm{p}=0.23$ & \\
\hline \multicolumn{7}{|l|}{ use of vitamin $A$} \\
\hline never & $88 \%$ & $90 \%$ & 1.00 & & 1,00 & \\
\hline in winter & $9 \%$ & $7 \%$ & 1.33 & $<0.76-2.32\rangle$ & 1.70 & $<0.79-3.65\rangle$ \\
\hline all year & $4 \%$ & $3 \%$ & 1.16 & $<0.49-2.70>$ & 0.76 & $<0.26-2.26>$ \\
\hline Test for trend & & & $\mathrm{p}=0.38$ & & $p=0.74$ & \\
\hline \multicolumn{7}{|l|}{ use of vitamin $\mathrm{C}$} \\
\hline containing pills & $\mathrm{n}=255$ & $\mathrm{n}=704$ & & & & \\
\hline never & $82 \%$ & $83 \%$ & 1.00 & & 1.00 & \\
\hline in winter & $13 \%$ & $12 \%$ & 1.11 & $<0.70-1.75>$ & 0.66 & $\langle 0.34-1.26\rangle$ \\
\hline all year & $5 \%$ & $5 \%$ & 1.06 & $<0.53-2.08>$ & 0.50 & $\langle 0.21-1.20\rangle$ \\
\hline Test for trend & & & $p=0.70$ & & $p=0.06$ & \\
\hline
\end{tabular}

Next, we compared the intake of beta-carotene between the 46 women with an abnormal smear in the past on the one hand, and the remaining 648 women in the control group on the other. Table 3 shows that the women who had had an abnormal smear had a slightly higher dietary intake of beta-carotene than the women without an abnormal smear in their medical history. The average daily intake was $3.09 \mathrm{mgs}$ vs 2.65 mgs of beta-carotene. This observation is consistent with the results of the main analysis, in which the cases who participated in the randomized trial were compared to the control group sampled from the general population.

Table 3: Dietary intake of beta-carotene in the control group: 46 women with an abnormal smear in their medical history compared with the rest of the control grouj].

\begin{tabular}{lllll}
\hline & $\begin{array}{c}\text { women with } \\
\text { abnormal smear }\end{array}$ & $\begin{array}{c}\text { women without } \\
\text { abnormal smear }\end{array}$ & $\begin{array}{c}\text { crude } \\
\mathrm{OR}\end{array}$ & $95 \% \mathrm{CI}$ \\
\hline beta-carotene & $(\mathrm{n}=46)$ & $(\mathrm{n}=648)$ & & \\
$51.5 \mathrm{mg}$ & $28 \%$ & $29 \%$ & 1.00 & \\
$1.5-2.5 \mathrm{mg}$ & $17 \%$ & $27 \%$ & 0.66 & $<0.25-1.76>$ \\
$2.5-3.5 \mathrm{mg}$ & $28 \%$ & $21 \%$ & 1.40 & $<0.59-3.32>$ \\
$>3.5 \mathrm{mg}$ & $26 \%$ & $22 \%$ & 1.21 & $<0.50-2.92>$ \\
Test for trend & & & $p=0.36$ & \\
\hline
\end{tabular}


In order to get an indication of the dietary factor(s) which influence(s) the risk for cervical dysplasia, we compared the consumption of individual food items or food groups between cases and controls. No relations were found with retinol containing foods. Table 4 shows the relations with foods containing beta-carotene, vitamin $\mathrm{C}$ and/or dietary fibre.

It appeared that cases consumed more carrots and spinach, two vegetables rich in betacarotene. Inverse relations were found for the consumption of tomatoes and all fruits. Among the fruits, an inverse relation was observed with the consumption of apples, but not with citrus fruits.

Table 4: Frequency of consumption of specilic food items and food groups in cases and controls: crude and adjusted odds ratios and $95 \%$ confidence intervals (CD).

\begin{tabular}{|c|c|c|c|c|c|c|}
\hline & cascs & controls & $\begin{array}{l}\text { crude } \\
\text { OR }\end{array}$ & $95 \% \mathrm{CI}$ & $\begin{array}{l}\text { adjusted } \\
\text { OR }\end{array}$ & $95 \% \mathrm{CI}$ \\
\hline \multicolumn{7}{|l|}{ carrots } \\
\hline (umes/month) & $\mathrm{n}=256$ & $\mathrm{n}=698$ & & & & \\
\hline$\leq 1$ & $32 \%$ & $35 \%$ & 1,00 & & 1.00 & \\
\hline 2 & $23 \%$ & $21 \%$ & 1.21 & $\langle 0.80-1.83\rangle$ & 1.39 & $\langle 0.82-2.36\rangle$ \\
\hline $3 \cdot 4$ & $30 \%$ & $29 \%$ & 1.14 & $\langle 0.78-1.67\rangle$ & 1.54 & $<0.94-2.53\rangle$ \\
\hline $\begin{array}{l}25 \\
\text { Test for trend }\end{array}$ & $16 \%$ & $14 \%$ & $\begin{array}{l}1.22 \\
p=0.37\end{array}$ & $\langle 0.76-1.95\rangle$ & $\begin{array}{l}2.00 \\
p=0.04\end{array}$ & $\langle 1.15-3.66\rangle$ \\
\hline \multicolumn{7}{|l|}{ spinach } \\
\hline$\underset{0}{\text { (times/month) }}$ & $\begin{array}{c}\mathrm{n}=256 \\
28 \%\end{array}$ & $\begin{array}{c}\mathrm{n}=698 \\
33 \%\end{array}$ & 1.00 & & 1.00 & \\
\hline 1 & $21 \%$ & $21 \%$ & 1.20 & $<0.78-1.85>$ & 1.23 & $\langle 0.71 \cdot 2.13\rangle$ \\
\hline 2 & $21 \%$ & $17 \%$ & 1.45 & $\langle 0.93-2.25\rangle$ & 1.88 & $\langle 1.08-3.28\rangle$ \\
\hline $\begin{array}{l}2^{3} \\
\text { Test for trend }\end{array}$ & $30 \%$ & $28 \%$ & $\begin{array}{l}1.30 \\
p=0.13\end{array}$ & $<0.88-1.92>$ & $\begin{array}{l}1.59 \\
p=0.06\end{array}$ & $<0.97-2.61\rangle$ \\
\hline \multicolumn{7}{|l|}{ kale } \\
\hline (iimes/month) & $\begin{array}{c}n=256 \\
59 \%\end{array}$ & $\begin{array}{c}\mathrm{n}=698 \\
65 \%\end{array}$ & 1.00 & & 1.00 & \\
\hline 1 & $18 \%$ & $15 \%$ & 1.32 & $\langle 0.87-1.99\rangle$ & 1.38 & $<0.80-2.40\rangle$ \\
\hline 2,3 & $18 \%$ & $13 \%$ & 1.59 & $\langle 1.05-2.41\rangle$ & 1.99 & $\langle 1.15-3.42\rangle$ \\
\hline Test for trend & $5 \%$ & $7 \%$ & $\begin{array}{l}0.91 \\
p=0.16\end{array}$ & $<0.46-1.76\rangle$ & $\begin{array}{l}1.07 \\
p=0.29\end{array}$ & $<0.45-2.53\rangle$ \\
\hline \multicolumn{7}{|l|}{ other cabbages } \\
\hline (times/month) & $\mathrm{n}=255$ & $\mathrm{n}=698$ & & & & \\
\hline$\leqslant 1$ & $20 \%$ & $21 \%$ & 1.00 & & 1.00 & \\
\hline $2 \cdot 3$ & $25 \%$ & $24 \%$ & 1.14 & $<0.72-1.79\rangle$ & 1.45 & $<0.81-2.58\rangle$ \\
\hline $4-5$ & $19 \%$ & $29 \%$ & 0.72 & $\langle 0.45-1.16\rangle$ & 0.73 & $\langle 0.40-1.34\rangle$ \\
\hline $\begin{array}{l}6 \\
\text { Test for trend }\end{array}$ & $37 \%$ & $26 \%$ & $\begin{array}{l}1.54 \\
p=0.10\end{array}$ & $\langle 1.01-2.36\rangle$ & $\begin{array}{l}1.88 \\
p=0.28\end{array}$ & $\langle 1.06-3.31\rangle$ \\
\hline
\end{tabular}




$\begin{array}{lllll} & \text { crude } & & \text { adjusted } & \\ \text { cases controls } & \text { OR } & 95 \% \mathrm{Cl} & \text { OR } & 95 \% \mathrm{Cl}\end{array}$

pulses

(times/month)

$\begin{array}{cc}\mathrm{n}=255 & \mathrm{n}=698 \\ 13 \% & 12 \% \\ 16 \% & 12 \% \\ 31 \% & 34 \% \\ 40 \% & 43 \%\end{array}$

$$
1.00
$$

2

3-4

25

$34 \%$

1.21

0.81

0.85

$\mathrm{p}=0.22$

$\begin{array}{ll}<0.67-2.18\rangle & 1.00 \\ <0.49-1.34\rangle & 1.14 \\ \langle 0.52-1.39\rangle & 0.99 \\ & 1.00 \\ & p=0.87\end{array}$

$\langle 0.53-2.43\rangle$

$<0.51-1.89>$

$<0.53+1,90>$

Test for trend

tomatoes

(times/week)

$\begin{array}{cc}\mathrm{n}=257 & \mathrm{n}=702 \\ 29 \% & 23 \% \\ 25 \% & 22 \% \\ 17 \% & 19 \% \\ 29 \% & 36 \%\end{array}$

1.00

0.90

0.72

0.63

$\geq 3$

1

2

Test for trend

$\mathrm{p}=0.01$

$$
\begin{array}{ll} 
& 1.00 \\
<0.59-1.37\rangle & 0.88 \\
\langle 0.45-1.14\rangle & 0.73 \\
\langle 0.42-0.94\rangle & 0.58 \\
& p=0.01
\end{array}
$$

$<0.51-1.52>$

$\langle 0.40-1.34\rangle$

$<0.33-1.02>$

all fruits

(times/day)

$\begin{array}{ccc}0 & 16 \% & 7 \% \\ 1 & 43 \% & 37 \% \\ 2 & 27 \% & 35 \% \\ 3 & 14 \% & 20 \%\end{array}$

1.00

0.52

0.35

0.30

Test for trend

$\mathrm{p}=0.00$

$<0.32-0.85\rangle$

1.00

$\langle 0.21-0.59\rangle \quad 0.42$

$<0.17-0.54>$

0.29

$\mathrm{p}=0.06$

$<0.25-0.92\rangle$

$<0.21-0.83\rangle$

$<0.13-0.63\rangle$

apples

(times/day)
0
1
22

Test for trend

$\begin{array}{cc}\mathrm{n}=256 & \mathrm{n}=703 \\ 48 \% & 31 \% \\ 47 \% & 59 \% \\ 6 \% & 10 \%\end{array}$

1.00

0.51

0.33

$\mathrm{p}=0.00$

$$
\begin{array}{ll}
<0.38-0.70> & 1.00 \\
<0.17-0.64> & 0.59 \\
& 0.42 \\
& p=0.01
\end{array}
$$

$<0.39 \cdot 0.80>$

$<0.19-0.94>$

citrus fruits

(times/day)

0

1

$\geq 2$

Test for trend

$\mathrm{n}=256 . \quad \mathrm{n}=703$

$55 \% \quad 47 \%$

1.00

0.70

$35 \%$

$44 \%$

0.93

$p=0.13$

$<0.51-0.96>$

1.00

0.73

$<0.55 \cdot 1.58>$

1.27

$p=0.76$

$<0.48-1.11>$

$<0.63-2.56>$

orange juice

(glasses/week)

0
$1-2$
$3-5$
26
Test for trend

$\mathrm{n}=255 \quad \mathrm{n}=705$

$33 \% \quad 29 \%$

$18 \% \quad 19 \%$

$11 \% \quad 14 \%$

1.00

1.00

$\begin{array}{lll}1.10 & <0.77-1.57\rangle & 0.98\end{array}$

$0.88<0.58-1.36\rangle \quad 0.77$

$0.72<0.43-1.78>$

0.77
0.49

$\langle 0.61-1.58\rangle$

$\langle 0.44-1.33\rangle$

$\mathrm{p}=0.16$

$p=0.06$ 


\section{Discussion}

This study gives no indication that a high dietary intake of beta-carotene protects against the development of cervical dysplasia. On the contrary, we even found a slightly higher risk of cervical dysplasia for the classes with the highest intake of beta-carotene. No relation could be shown with the intake of retinol. The intake of dietary fibre, dietary vitamin $C$ and vitamin $C$ pills appeared to have a weak inverse relation with the risk for cervical dysplasia.

We will first discuss our findings with respect to the internal validity of our study, and then compare results of our study with other studies on this subject.

In case-control studies the major problems of validity relate to the choice of the study population, to the comparability of information obtained from cases and controls and to the presence of confounding factors (9).

The cases involved in this study formed a selection of patients with cervical dysplasia. They were willing to participate in a randomized trial in which the effect of a supplementall dose of beta-carotene on dysplasia was assessed. It is thinkable that patients interested in nutrition were especially willing to participate, or that they might be alerted to change their food habits. Although they were only told that we were interested in the effect of dietary factors on cervical dysplasia, without mentioning the term beta-carotene or vitamin $A$, an increased consumption of fruit and vegetables is generally considered a component of a healthy diet. This might explain our observation that the cases had a higher intake of beta-carotene than the controls. However, the women in the control group with an abnormal smear, who were not in any way influenced by information about the randomized trial, also showed a slightly higher intake of beta-carotene than the rest of the control group. Thus, our case group did not seem to be selective in this respect.

Our control group was selected as a sample of the general population. This choice implied that we were not sure whether the controls were free of cervical dysplasia. The questionnaire inquired about abnormal smears in the past. This resulted in a varying degree of uncertainty with respect to the prevalence of cervical dysplasia in subgroups of the control group. For the 159 respondents who reported that they had never had a smear, it is unknown whether they have cervical dysplasia or not. For the controls who reported only negative smears we have no data on when the last smear was made. Some of the women in this group may have developed cervical dysplasia since. There were 46 women who reported to have had an abnormal smear in the past, 16 of whom in the last two years. The degree of certainty about the presence of cervical dysplasia in these cases depends on the validity of the cytological diagnosis. We did not check whether the dysplastic lesions were histologically confirmed. It was especially with respect to these 46 women that we had to decide whether to include or exclude them. On the basis of the principles of Miettinen on case-referent studies (11), we opted for 
inclusion. This meant that problems could occur if the disease influenced the risk factors under study. Assuming that an abnormal smear does not change a person's food habits, it was justifiable to include the women with an abnormal smear in the control group. We chose this option in the main analysis and performed an additional analysis using the women with an abnormal smear in their medical history as a separate cases group.

Excluding the women with an abnormal smear in the past from the control group would have slightly increased the contrast between the cases and the controls with respect to the intake of beta-carotene, as the excluded women had a relatively high intake of betacarotene.

There was considerable non-response in the control group (33\%). We think that the reasons for not returning the questionnaire must be sought in the reluctance to participate in any research, or to answer intimate questions about sexual habits, rather than in reasons related to food habits. The non-response in the cases group (15\%) was mainly due to the fact that these women had stopped participation in the experiment for other reasons. Thus we think that our cases and controls were not selective with regard to dietary habits.

The study population received a postal questionnaire. In this way we expected more trustworthy answers on the questions about sexual habits than in a personal interview. However, a postal questionnaire requires the questions to be easy to interpret and answer. Therefore the questions about the food habits necessarily had to be simple, and extensive measurements of portion size were not performed.

Information bias is introduced if either cases or controls, wittingly or unwittingly, overreport or underreport on risk factors. There is no reason to believe that this was the case, as the circumstances were equal: the same questionnaire and no interviewer bias (9).

We collected information about the most important risk factors of cervical dyplasia because they could potentially confound the relation between dietary factors and cervical dysplasia. In the logistic regression analysis we adjusted for all relevant confounding factors simultaneously. However "this does not exclude bias due to unmeasured confounders, nor residual confounding due to imprecise measurement. Confounding may be an important problem in studies on dietary factors. Since some dietary factors, for example beta-carotene, vitamin $\mathrm{C}$ and dietary fibre, occur chiefly in the same foods (vegetables and fruits), they are usually highly correlated. Therefore, they are potential confounders when the effect of associated dietary factors is studied. In our study the intake of beta-carotene, vitamin $\mathrm{C}$ and dietary fibre were not correlated with the intake of retinol. The correlation coefficients for the intake of betacarotene with, respectively, the intake of vitamin $\mathrm{C}$ and that of dietary fibre was 0.30 and 0.47 , while the correlation coefficient for the intake of vitamin $C$ with the intake of dietary fibre was 0.45 . 
The rather impressive changes in some odds ratios after adjustment for confounding illustrates the importance of adjustment, but, at the same time, results in the uneasy feeling that residual confounding, due to either imprecise measurement or to unmeasured confounders, may still be substantial.

Cervical dysplasia, carcinoma in situ (c.is.) and invasive cervical carcinoma are considered to be stages in a continuum of one single disease (12), with the same set of risk factors, although the lower grades of dysplasia may include nonspecific reactions of the cervical epithelium (13).

Several other studies have assessed the relation between dietary factors and cervical cancer, or its precursors. One study showed that patients with cervical dysplasia, especially those with severe dysplasia and c.i.s., had a lower dietary intake of betacarotene and vitamin $\mathrm{C}$ than controls without dysplasia $(14,15)$.

In two studies no difference in the dietary intake of beta-carotene was observed between patients with precursors of cervical cancer and women without abnormalities in the cervix, although the cases had a lower level of beta-carotene in their serum $(16,17)$. An inverse relation was reported for vitamin $C$ and especially fruit juices (17). Two other case-control studies reported an inverse relation between the intake of betacarotene and the risk for cervical cancer $(18,19)$. In one of these studies, the consumption of cruciferous vegetables (such as cabbage) appeared to increase the risk of cervical cancer, while no relations were observed for vitamin $\mathrm{C}$ and dietary fibre (18).

In a recent case-control study no relation was found between invasive cervical cancer and the dietary intake of beta-carotene, retinol and vitamin $C(20)$.

Thus studies on the relation between dietary factors and cervical cancer or its precursors show inconsistent results. The only consistent finding is the absence of a relation with dietary retinol (17-20). Beta-carotene and vitamin $\mathrm{C}$ show a protective effect in some studies $(14,15,18,19)$, but no effect is observed in others $(16,17,20)$. In our study, the inverse relation with the consumption of apples and tomatoes was most pronounced. Weak inverse relations were found with vitamin $\mathrm{C}$ and dietary fibre. However, notwithstanding the inconsistencies, all studies, except for one (20), point in the same direction: a factor which is present in vegetables or fruits or highly correlated with the consumption of vegetables or fruits appears to be inversely related with the risk for cervical cancer or its precursors. From our case-control study it seems unlikely that beta-carotene is this specific factor. 


\section{References}

1. Peto R, Doll R, Buckley JD, Sporn MB. Can dietary beta-carotene materially reduce human cancer rates? Nature 1981; 290: 201-208.

2. Mettlin C. Epidemiological studies on vitamin A and cancer. Adv Nutr Res 1984; 6: 47-65.

3. Vet $\mathrm{HCW}$ de. The puzzling role of vitamin $\mathrm{A}$ in cancer prevention. Anticancer Res 1989; 9: 145-151.

4. Ziegler RG. A review of epidemiologic evidence that carotenoids reduce the risk of cancer. J Nutr 1989; 119: 116-122.

5. Brandt PA van den, Goldbaum RA, Veer $P$ van 't, Hermus RJJ, Sturmans F. Dietary habits and the aetiology of cancer. Int J Epidemiol 1988; 17: 472.

6. NEVO-tabel. Aanbevolen hoeveelheden energie en voedingsstoffen. The Hague: Voorlichtingsbureau voor de Voeding, 1983.

7. Ministerie van Welzijn, Volksgezondheid en Cultuur en Ministerie van Landbouw en Visserij. Wat eet Nederland? Resultaten van de voediselconsumptiepeiling 1987 1988. Rijswijk, 1988 .

8. Breslow NE, Day NE. Statistical methods in cancer research. The analysis of casecontrol studies (Vol 1). IARC Scientific Publications No. 32. Lyon: IARC, 1980.

9. Rothman KJ. Modern epidemiology. Boston, Toronto: Little, Brown and Company, 1986.

10. Dixon DJ (ed.). BMDP statistical software, Berkeley, Los Angeles, London: University of California Press, 1985.

11. Miettinen OS. Theoretical epidemiology. Principles of occurrence research in medicine. New York: John Wiley \& Sons, 1985.

12. Koss LG. Dysplasia. A real concept or a misnomer? Obstet Gynaecol 1978; 51: 374-379.

13. Terras $\mathrm{M}$, Wilson $\mathrm{F}$, Nelson $\mathrm{JH}$. Comparative epidemiology of invasive carcinoma of the cervix, carcinoma in situ, and cervical dysplasia. Am J Epidemiol 1980; 112: 253-257.

14. Wylie-Rosett JA, Romney SL, Slagle NS, et al. Influence of vitamin A on cervical dysplasia and carcinoma in situ. Nutr Cancer 1984; 6: 49-57.

15. Wassertheil-Smoller S, Romney SL, Wylie-Rosett JA, et al. Dietary vitamin C and uterine cervical dysplasia. Am J Epidemiol 1981; 114: 714-724.

16. Bernstein A, Harris B. The relationship of dietary and serum vitamin $A$ to the occurrence of cervical intraepithelial neoplasia in sexually active women. Am J Obstet Gynaecol 1984; 148: 309-312.

17. Brock KE, Berry G, Mock PA, MacLennan R, Truswell AS, Brinton LA. Nutrients in diet and plasma and risk of in situ cervical cancer. J Natl Cancer Inst 1988; 80: 580-585.

18. Marshall JR, Graham S, Byers T, Swanson M, Brasure J. Diet and smoking in the epidemiology of cancer of the cervix. J Natl Cancer Inst 1983; 70: 847-851. 
19. LaVecchia $\mathrm{C}$, Franceschi $\mathrm{S}$, Decarli A, et al. Dietary vitamin $\mathrm{A}$ and the risk of invasive cervical cancer. Int $J$ Cancer $1984 ; 34: 319-322$.

20. Ziegler RG, Brinton LA, Hamman RF, et al. Diet and the risk of invasive cervical cancer among white women in the United States. Accepted for publication by Am J Epidemiol. 
Chapter 4

\section{THE EFFECT OF BETA-CAROTENE ON CERVICAL DYSPLASIA} Rationale and implications of a study design*

Henrica C.W. de Vet, Paul G. Knipschild

Department of Epidemiology/Health Care Research, University of Limburg, Maastricht, The Netherlands

* Submitted for publication 


\begin{abstract}
In order to investigate whether beta-carotene plays a role in cancer prevention, we designed a randomized placebo-controlled trial For efficiency reasons, we decided to study the effect of beta-carotene on the regression and progression rates of cervical dysplasia during a fixed period or time. The rationale and implications of this study design are discussed.
\end{abstract}




\section{Introduction}

There is reason to believe that beta-carotene protects against cancer $(1,2)$. We have investigated this matter in a study which was both informative and feasible within a five year period, using a limited number of subjects. However, many critical decisions had to be taken on theoretical, methodological and practical issues. The rationale and implications of the study design will be discussed in this paper.

\section{Vitamin $A$, beta-carotene and cancer}

In several case-control and cohort studies a relation has been observed between a low consumption of vegetables and fruits and a high cancer incidence (3). Some of these studies focused on the intake of vitamin $A$, others on vitamin $C$ or other compounds. The question that arises from these studies is whether the effect should be attributed to beta-carotene, to vitamin $\mathrm{C}$, or to other compounds present in vegetables and fruits, or perhaps to one or more factors which are strongly associated with the consumption of vegetables and fruits. It is difficult to infer from non-experimental studies which of these factors might be responsible for the protective effect, since they usually show a high correlation in food consumption studies. Although a role of vitamin $\mathrm{C}$ or another compound cannot be excluded $(4,5)$, most evidence points to a relation between vitamin $\mathrm{A}$ and cancer $(3,5)$. Two components are responsible for the vitamin $\mathrm{A}$ activity, viz. retinol and that part of some carotenoids that can be converted into retinol. Of the convertible carotenoids, beta-carotene contributes most to the vitamin A activity, as it occurs in many vegetables and fruits and is efficiently converted into retinol. As a result, of all the carotenoids, beta-carotene has been most often studied in relation to cancer. Non-experimental epidemiological studies differentiating between the effect of dietary intake of retinol and that of dietary intake of beta-carotene showed, almost without exception, that the preventive effect can most likely be attributed to betacarotene (2). It is not certain yet whether the ultimate effect is exerted by carotene itself, or whether conversion into retinol is required. In theory, both components have anti-carcinogenic properties. Carotenoids, especially beta-carotene, are potent antioxidants, which may protect against cancers induced by free radicals. Retinol is known to have an effect on the maintenance of differentiation of epithelial tissues, and via this mechanism (or maybe another) it may play a role in cancer prevention. Thus, there seems to be reasonable evidence that beta-carotene is able to protect against cancer, either as beta-carotene or after conversion into retinol. Therefore, an attempt at confirmation of its effect in a randomized experiment is justifiable. As betacarotene is a non-toxic compound, such an experiment is also ethically acceptable. 


\section{Cervicall dysplasia}

\section{Choice of cervical dysplasia}

The incidence of cancer in healthy individuals is very low. Therefore a large study population would be needed to study the effect of beta-carotene on the etiology of cancer. For that reason we decided to perform a study in a population with a precancerous lesion. Of the warious cancer sites, dysplasia of the uterine cervix was chosen, because it is a neoplasm with a high prevalence rate, which is easily accessible and detected, and amenable to follow-up with little discomfort and relative safety for the patient. Moreover, a relation between beta-carotene intake and cervical dysplasia or cervical carcinoma has been reported in several case-control studies $(6,7,8)$. Thus, it was primarily for reasons of efficiency that we decided to study the effect of beta-carotene on a precancerous lesion. In a study on the prognosis of cervical dysplasia, either the regression and progression rates of various stages of cervical dysplasia or the duration of the various stages can be investigated. However gynaecologists tend to intervene at the more advanced precursor stages. For that reason, progression to the more severe stages cannot be studied. Sometimes persistence of the dysplasia is also an indication for therapeutic intervention, which makes a study of the duration of the various stages problematic. On the basis of these considerations we decided to study the regression and progression percentages of newly detected cervical dysplasia during a fixed period of medication with beta-carotene and placebos.

\section{Duration of the intervention period}

From a scientific point of view, the period of intervention and follow-up should be as long as possible, while from the point of view of optimal health care, its duration must be acceptable to both gynaecologists and patients. The acceptable duration of the intervention period was determined in discussions with gynaecologists, which resulted in a period of three months. It is assumed that the effect of beta-carotene on cervical dysplasia, if present, appears within this period. This is not an unrealistic view, as epithelial tissues are characterized by a high mitotic activity and hence a high turnover rate. The portio epithelium is completely replaced by a new population of cells every 4 to 5 days (9). Dietary beta-carotene reaches all tissues in a short time. So, if betacarotene affects the late stages of the cancer process, the effect should be observable within three months.

\section{Outcome parameter}

The progression and regression rates were assessed by comparing the diagnosis at admission with the diagnosis after three months of medication, either with betacarotene or placebo. The most sensitive definition of progression and regression is the transition to, respectively, a more severe or a less severe stage. Thus, the change of moderate dysplasia to severe dysplasia is labeled progression, while the change of moderate dysplasia to mild dysplasia is regarded as regression. A less sensitive, but clinically more relevant, definition is that in which the transition of dysplasia to 
carcinoma in situ or invasive carcinoma is called progression, while regression means that the dysplasia has disappeared completely. The choice between these two options depends on the precision of the diagnosis. If there is too much misclassification, it will not be easy to detect small changes, and detectable changes cannot be quantified adequately.

An important decision in this trial was whether the presence of dysplasia at admittance should be established by means of a histological diagnosis or whether a cytological diagnosis would be sufficient. A histological diagnosis is generally considered more valid (10). On the other hand, a histological diagnosis is thought to interfere with the 'natural course' of cervicall dysplasia $(11,12)$. The argument was settled by the fact that gynaecologists normally take a biopsy in cases where the cytological diagnosis suggests cervical dysplasia. For that reason we considered a histological diagnosis of cervical dysplasia, on the basis of a punch biopsy, mandatory for all patients before admittance to the study.

If it is true that a biopsy causes regression of dysplasia in some cases, then part of the regression observed in the experimental group may be due to the biopsy. However, biopsies are also taken in the control group, and these should cause the same rate of regression, if any. This leaves the opportunity to assess the regression which is due solely to beta-carotene.

\section{Beta-carotene and cervical dysplasia}

A crucial question at this point was whether beta-carotene has any influence on this late stage of the cancer process. Beta-carotene may exert its antioxidative influence wherever oxygen radicals are involved in the cancer process. These radicals are known to affect both the initiation and promotion stages (13). The effects of carotenoids have most frequently been studied in relation to UV-induced skin tumors. It was found that most of the carotenoids, including those without vitamin $\mathrm{A}$ activity, showed a protective effect against these tumors, whether UV radiation was used as initiating or as promoting agent (14). Whether carotenoids, without conversion into retinol, have an effect on a phase of the cancer process in which a precancerous lesion is already present, has never been reported.

In a review article on vitamin $A$ and cancer prevention (2) it was inferred that betacarotene probably exerts its effect after conversion into retinol. The effect on cancer of retinol and its (synthetic) derivatives, the retinoids, has been extensively studied. In humans, preventive as well as therapeutic effects of retinoids on various precancerous and cancerous lesions have been reported (15). Uncontrolled trials have shown promising results for topical application of retinoids in the cervix, by means of a collagen sponge or as a gel $(16,17)$.

Hence, it seems reasonable to assume that a high dietary intake of beta-carotene may influence cervical dysplasia, either as beta-carotene or after conversion into retinol. Another critical choice was the dose of beta-carotene. We wanted to be sure that the experimental group had a much higher intake than the control group, while on the 
other hand, we wanted to prevent yellowing of the skin. One study reported skin yellowing by over $50 \%$ of the persons taking a daily beta-carotene supplement of $30 \mathrm{mg}$ (18). The mean dietary intake of beta-carotene in the Netherlands is 2-3 mg a day (19). On the basis of these findings we chose for a daily dose of $10 \mathrm{mg}$.

\section{The actual study design}

A multicenter blinded randomized trial was organized by our Department (Epidemiology/Health Care Research, University of Limburg, Maastricht). Gynaecologists from 23 hospitals in the Netherlands recruited patients for the trial. The randomization was performed by the Department of Clinical Pharmacy of the 'Maasland' Hospital in Sittard, a town near Maastricht.

\section{Study population}

We aimed at enrolling approximately 350 patients in the trial. During the years 19841987 , a total of 333 eligible patients, aged 20-65, with a histological diagnosis of cervical dysplasia were admitted to the trial, 55 of whom dropped out during the study for various reasons. This left us with 278 patients for further analysis. Gynaecologists have different policies concerning the stage of dysplasia at which they intervene in the process. Therefore, we entrusted the individual gynaecologists with the decision about the stages of dysplasia at which they were willing to admit patients to the study. Thus, the criterion for inclusion was any case of cervical dysplasia for which a three month waiting period without therapeutic intervention was considered acceptable to both gynaecologist and patient. An additional criterion was that the patient had not been treated for dysplasia in the past. Women who were pregnant or had been so in the last three months were not eligible, because cervical tissue changes during and just after pregnancy. Moreover, as teratogenic effects of retinoids have been reported, we excluded pregnant women as a precautionary measure. In addition, women with diabetes mellitus or a severe dysfunction of the bowels or liver were excluded because of possible abnormalities in the absorption or metabolism of beta-carotene.

\section{Informed consent}

If a patient was considered eligible, the gynaecologist explained the goal of the study to her. The patient was told that a food supplement was being tested, and that she had a 50 per cent chance to receive the placebo medication. After oral consent, the patient also received written information. Patients were allowed to withdraw from the study at any time. The protocol was approved by the Ethical Committees of the University and participating hospitals.

\section{Randomization}

In order to achieve an equal distribution of the degree of dysplasia over the groups to be compared, we used a stratified randomization scheme (20). Three degrees of dysplasia were distinguished, viz. mild, moderate and severe dysplasia. In addition, 
prestratification was applied according to the hospital which recruited the patients and according to age. Two age categories were used: $\leq 35$ years and $>35$ years. This method of stratified randomization anticipates on an unbalanced distribution of these prognostic indicators over the beta-carotene and placebo groups.

\section{Multi-blind}

The study was blinded in many respects. The patients who received the medication, the gynaecologists who examined the patients and decided which patients were eligible for the study, the pathologists who judged the pathological material, were all blinded. And the investigators, who took care of the administration and decided which patients should be excluded from the analysis, were blinded as well. The randomization code was only known to members of the Department of Clinical Pharmacy, none of whom had any influence on patient selection, diagnosis or other decisions in the trial.

\section{Medication and compliance}

The medication was mailed to the patients' home address. The patients assigned to the experimental group received a box with 100 beta-carotene capsules (containing $10 \mathrm{mg}$ each), of which they had to take one capsule a day, preferably during dinner. The control group received a box with 100 placebo capsules, with similar instructions. All capsules were prepared by Hoffmann-La Roche.

Compliance was assessed by pill counts and through a questionnaire. The questionnaire included the question: 'How many times a week on average do you forget to take your medication'? The patient was instructed to return any remaining capsules to the gynaecologist when she had her follow-up visit. The gynaecologist informed us about the number of capsules returned.

\section{Additional information}

After two months of participation the patient was asked to fill in a questionnaire which inquired about food habits, with special reference to the intake of beta-carotene, retinol, vitamin $\mathrm{C}$ and dietary fibre, and about other risk factors for cervical dysplasia, including sexual habits. We used these data to check the success of the randomization and to adjust for any residual confounding in a multivariate analysis.

\section{Outcome parameter}

The outcome parameter was based on the difference in the degree of dysplasia before and after the three months of medication.

At entry we required a histological diagnosis of cervical dysplasia. The gynaecologists used a colposcope to take a biopsy from the most severely affected area of the cervix. At the follow-up visit the gynaecologists examined the patient's cervix cytologically and sometimes also histologically. We asked for a cytological diagnosis and preferably also a histological diagnosis. If the gynaecologist considered a biopsy not indicated, on the basis of the cytological diagnosis and/or the colposcopic appearance, the histological diagnosis was omitted. 


\section{Discussion}

Our objective to perform a study with not too many subjects, which would not take too much time, prompted us to make a design based on several assumptions. The choice to study the regression and progression rates of cervical dysplasia required the assumption that beta-carotene has an important effect on cervical dysplasia. The dose of betacarotene to be used was also a critical decision, as was the duration of the period of medication.

If there is a positive study result, i.e. if the carotene group shows a higher regression percentage than the placebo group, many of the abovementioned choices would turn out to be right: the stage of the cancer process was properly chosen, the dose of betacarotene was high enough, the duration of the period of medication long enough. However, if beta-carotene is not found to have an effect, many explanations can be put forward. One, of course, is that beta-carotene does not protect against cancer at all. Alternative explanations would be that beta-carotene does not affect this stage of the cancer process, or that the three month period was too short. Other reasons for a negative result might be a therapeutic effect of the biopsies (which would leave less of an opportunity for an effect of beta-carotene), lack of compliance of the patients in taking their medication, or lack of precision in the measurement of the outcome parameter by the pathologists. 


\section{References}

1. Peto R, Doll R, Buckley JD, Sporn MB. Does dietary beta-carotene materially reduce human cancer rates? Nature 1981; 290: 201-208.

2. Vet $\mathrm{HCW}$ de. The puzzling role of vitamin $A$ in cancer prevention. Anticancer Res 1989; 9: 145-151.

3. Byers T, Graham S. The epidemiology of diet and cancer. Adv Cancer Res 1984; 11: $1-68$.

4. Cameron E, Pauling L, Leibovitz B. Ascorbic acid and cancer: a review. Cancer Res 1979; 39: 663-681.

5. Willett WC, MacMahon B. Diet and cancer - an overview. New Engl J of Med. 1984; 30: 633-638.

6. Romney SL, Palan PR, Duttagupta C, et al. Retinoids and the prevention of cervical dysplasias. Am J Obstet Gynecol 1981; 141: 890-894.

7. Marshall JR, Graham S, Byers T, Swanson M, Brasure J. Diet and smoking in the epidemiology of cancer of the cervix. $J$ Natl Cancer Inst 1983; 70: 847-851.

8. LaVecchia C, Franchesci S, Decarli A, et al. Dietary vitamin A and the risk of invasive cervical cancer. Int J Cancer 1984; 34: 319-322.

9. Ferenczy A. Cervical intra-epithelial neoplasia. In: Pathology of the female genital tract. Blaustein A. ed. New York, Heidelberg, Berlin. Springer Verlag 1977, p.143165.

10. Briggs RM. Dysplasia and early neoplasia of the uterine cervix, a review. Obstet Gynecol Survey 1979; 34: 70-99.

11. Koss LG, Stewart FW, Foote FW, Jordan MJ, Bader GM, Day E. Some histological aspects of behavior of epidermoid carcinoma in situ and related lesions of the uterine cervix. Cancer 1963; 16: 1160-1211.

12. Richart RM. Influence of diagnostic and therapeutic procedures on the distribution of cervical intraepithelial neoplasia. Cancer 1966; 19: 1635-1638.

13. Ames BN. Dietary carcinogens and anticarcinogens. Oxygen radicals and degenerative diseases. Science 1983; 221: 1256-1264.

14. Mathews-Roth MM. Antitumor activity of beta-carotene canthaxanthin and phytoene. Oncology 1982; 39: 33-37.

15. Lippman SM, Kessler JF, Meyskens FL. Retinoids as preventive and therapeutic anticancer agents (part II). Cancer Treat Rep 1987; 71: 493-515.

16. Peng YM, Alberts DS, Graham V, et al. Cervical tissue uptake of all-transretinoic acid delivered via a collagen sponge-cervical cap delivery device in patients with cervical dysplasia. Invest New Drugs 1986; 4: 245-249.

17. Graham V, Surwit EA, Weiner SA, et al. Phase II trial of beta-all-trans-retinoic acid for cervical intraepithelial neoplasia delivered via a collagen sponge and cervical cap. West J Med 1986; 145: 192-195.

18. Willett WC, Stampfer MJ, Underwood BA, Taylor JO, Hennekens CH. Vitamins A, E and carotene: effects of supplementation on their plasma levels. Am J Clin Nutr 1983; 38: 559-566. 
19. Hartog C. den, Schaik ThFSM van, Dalderup LM, Drion EF, Mulder T. The diet of volunteers participating in a long term epidemiological field survey on coronary heart disease at Zutphen, the Netherlands. Voeding 1965; 26: 184-208.

20. Pocock SJ. Clinical Trials. A practical approach. Chicester, New York: John Wiley \& Sons, 1987. 
Chapter 5

THE EFFECT OF BETA-CAROTENE ON THE REGRESSION AND PROGRESSION OF CERVICAL DYSPLASIA: A CLINICAL EXPERIMENT*

Henrica C.W. de Vet ${ }^{1}$, Paul G. Knipschild ${ }^{1}$, Dirk Willebrand ${ }^{2}$, Hubert J.A. Schouten ${ }^{3}$, Ferd Sturmans ${ }^{1}$

1 Department of Epidemiology/Health Care Research,

2 Department of Pathology,

3 Department of Medical Informatics and Statistics, University of Limburg, Maastricht, the Netherlands

* Submitted for publication 


\begin{abstract}
In order to gain insight into the causality of the relation between beta-carotene and cancer, we performed a randomized placebo-controlled trial in which the effect of beta-carotene on the regression and progression rates of cervical dysplasia were examined. The experimental group $(\mathrm{N}=137)$ received a supplemental dose of $10 \mathrm{mg}$ of beta-carotene daily for three months. The control group $(\mathbb{N}=141)$ received placebo capsules. As outcome parameter, two definitions of regression and progression were used, which were based on the degree of dysplasia before and after the medication period. The number of patients who showed progression was too small to allow conclusions. No effect of beta-carotene on the regression percentages was observed: OR $=0.68(95 \% \mathrm{CI}: 0.28$ to 1.60$)$ using the broad definition, and $\mathrm{OR}=1.22(95 \% \mathrm{Cl}$ : 0.43 to 3.41 ) with the strict definition. A secondary analysis, in which the effect of the total intake of beta-carotene (diet + medication) on the regression percentages of cervical dysplasia was studied, did not show a positive effect either. The paper discusses to what extent issues in the study design may have masked a potential effect and how our results affect the evidence for a causal relation between beta-carotene and cancer.
\end{abstract}




\section{Introduction}

In many non-experimental epidemiological studies a relation has been observed between a low intake of vegetables and fruits and a high cancer incidence $(1,2)$. Some of these studies focused on the intake of beta-carotene, others on vitamin $C$, indoles or other compounds. The question that arises from these studies is whether the effect is brought about by beta-carotene, by vitamin $C$, by another compound present in vegetables and fruits, or by a factor which is strongly associated with the consumption of vegetables and fruits. However, it is difficult to conclude from non-experimental studies which of these factors is responsible for the protective effect, because they are not only highly correlated, but they even occur in the same foods. The best documented relation is that between beta-carotene and cancer $(3,4)$. In our opinion, only experimental studies can answer the question whether the non-experimental studies are right in suggesting that: beta-carotene is causally related to cancer. Such experiments are ethically feasible, because beta-carotene is a non-toxic compound.

As the incidence of cancer in healthy individuals is very low, a large study population would be needed to study the effect of beta-carotene on the etiology of cancer. For that reason ${ }_{*}$ we decided to study the effect in a population with a precancerous lesion. Among the various cancer sites, cervical carcinoma was chosen because its precursor lesion, dysplasia, has a high prevalence rate, is easily accessible and easily detected, and is amenable to follow-up with little discomfort and relative safety for the patient. Moreover, a relation between beta-carotene and cervical dysplasia or cervical carcinoma has been reported in several case-control studies (5-8).

In our trial a supplemental dose of beta-carotene (10 $\mathrm{mg}$ per day) for three months was used to study its effect on the regression and progression rates of cervical dysplasia. The regression and progression rates were based on differences in the degree of cervical dysplasia before and after three months of medication.

\section{Methods}

\section{Organization}

This multicenter trial was coordinated by the Department of Epidemiology/Health Care Research, University of Limburg, Maastricht and approved by the Ethical Committees of that university and participating hospitals. Gynaecologists from 23 hospitals admitted 
patients to the trial*. The randomization took place in the Department of Clinical Pharmacy of the 'Malasland' hospital in Sittard, a town near Maastricht.

\section{Patient recruitment and entry criteria}

Women, aged 20 to 65 years, with a histological diagnosis of cervical dysplasia, who had not been treated previously, were eligible for this trial. Patients were excluded if they were pregnant or had been in the preceding three months, or if they reported diabetes mellitus or severe bowel or liver dysfunction in their medical history. A total number of 369 patients were enrolled in this trial.

\section{Informed consent}

When a patient was considered eligible, the gynaecologist gave oral information about the experiment. The patient was told that a (vitamin-like) food component was being tested, and that she had a 50 per cent chance to receive either the active medication or placebo medication. After oral consent of participation, the patient received written information about the experiment. The patient was allowed to withdraw from the study at any moment, by sending in a reply postcard.

\section{Randomization procedure}

At the moment of entry the principal investigator (HdV) sent the patient's data to the Department of Clinical Pharmacy of the 'Maasland' hospital in Sittard, where each patient was randomly assigned to the experimental group or the control group. Before randomization the patients were prestratified according to the hospital where they had been diagnosed, their age (two categories: $\leq 35$ years and $>35$ years), and degree of dysplasia (three categories: mild dysplasia; moderate dysplasia; severe dysplasia or carcinoma in situ (c.i.s.)). Within each stratum a blocked randomization scheme was applied with two patients in each block.

- Participating hospitals; coordinating gynecologists (number of admitted patients suitable for analysis): 'Do Wever" hospital, Heerlen, L.A Schellekens (48); 'Dijkzigt" hospital, Rotterdant, W.I. van der Meijden (28); University Hospital, Maastricht, H.I. de Koning Gans/T.H.M. Hasaart (26): 'St. Laurens' hospital, Breda, L.W.A.R. Berger/H.W.H. Feyen (23); 'Catharina" hospital, Eindhoven, J.A.M. van Wijck (20); 'Maria' hospital, Tilburg, P.J.H. van Vugt (16); 'St. Elisabeth' hospital, Heerlen, F.J.M.E. Roumen (15); 'Ignatius' hospital, Breda, S. Friese (12); 'St. Jans' hospital, Weert, J.A.F. van Erp (11); 'Groot ziekengasthuis', 's-Hertogenbosch, G.H.B. Broeders (10); 'Pieter Pauw' hospital, Wageningen, P.J.H. wan Kempen (10); 'Laurentius' hospital, Roermond, N.T.C.M. de Pree (10); 'Bergweg' hospital, Rotterdam, P.A.A. van Hagen (10); 'Streekziekenhuis' Bennekom, H.J.

Kwikkel (8); "Maasland" hospital, Geleen, J.M.G. Hollanders (7); University Hospital, Utrecht, J. Koudstaal (7); 'Elisabeth' hospital, Tilburg, J. de Graaff (5); 'Diakonessen' hospital, Breda, D.A. Gietelink (3); 'Streekziekenhuis Walcheren', Middelburg. F.A. de Schipper (3); 'Bleuland' hospital, Gouda, M. Helfferich (2); 'Maasland" hospital, Sittard, J.L.M.H. Specken (2); Medical Center 'Berg en Bosch', Bilthoven, Mw. M. Voslar-Zarchany (1); Hospital 'De Malberg', Arnhem, A.P.E. Schmoutziguer (1). 


\section{Multi-blind}

The patients who received the medication were blinded; the gynaecologists who decided which patients were eligible for the study and who examined the patients again after three months, as well as the pathologists who assessed the pathological slides were blinded. The investigators, who took care of the administration and decided which patients should be excluded from the analysis, were also blinded. Only the pharmacist knew the randomization code, but he had no influence on patient selection, diagnoses, or any other decision in the trial. The randomization code was disclosed after the elementary analysis of the data.

\section{Medication}

The medication was mailed to the patients' home addresses. The patients assigned to the experimental group received a box with 100 beta-carotene capsules (containing 10 mg each), of which they had to take one per day, preferably during dinner. The control group received a box with 100 indistinguishable placebo capsules, accompanied by similar instructions.

\section{Questionnaire}

After two months of participation each patient received a questionnaire which inquired, among other things, about food habits, with special reference to foods containing beta-carotene, retinol, vitamin $\mathrm{C}$ and dietary fibre. For a number of foods the frequency of use was assessed and for some foods also the portion size. From these data the intakes of beta-carotene, retinol, vitamin $\mathrm{C}$ and dietary fibre were estimated. The questionnaire also inquired about other risk factors for cervical dysplasia, including sexual habits. We used these data to check the success of randomization and, where necessary, to adjust for any remaining differences between the experimental and control groups in the analysis.

\section{Compliance}

Compliance was assessed by pill counts and through the questionnaire, which included the question: 'how many times a week on average do you forget to take the medication?' The same questionnaire instructed the patient to take the remaining capsules to the gynaecologist when she made her follow-up visit.

The gynaecologist informed us about the number of capsules returned. We constructed a compliance score using the most pessimistic scored parameter. For instance, if 15 capsules were returned and the patient reported complete compliance, the pill count was used; if zero capsules were returned and the patient reported that she forgot to take her capsules once a week, the patient's report was used. When data on one of the parameters were missing, the data on the other parameter were used and when data on both were missing it was assumed that compliance was very poor. 
Pathological diagnosis of cervical dysplasia

At entry we required a histological diagnosis of cervical dysplasia. The gynaecologists used a colposcope to take a biopsy from the most severely affected area of the cervix. At the follow-up examination the gynaecologists reexamined the patients' cervix, cytologically and/or histologically. We asked for a cytological diagnosis and preferably also a histological diagnosis. If the gynaecologist saw no reason for an additional biopsy because of the cytological diagnosis and/or the colposcopic appearance, the histological diagnosis could be omitted. The cytological diagnosis was classified in four categories: PAP I or II; PAP IIIA; PAP IIIB; PAP IV or V. The histological diagnosis was scored in five categories: no dysplasia; mild dysplasia; moderate dysplasia; severe dysplasia; c.i.s. As only one patient had a diagnosis of c.i.s. at entry in the study and only two patients after the medication period, we decided to use the classification scheme of cervical intraepithelial neoplasia (CIN) (9). In this classification scheme sewere dysplasia and c.i.s. are combined in the class CIN III, moderate dysplasia corresponds with CIN II and mild dysplasia with CIN I.

All histological diagnoses were reviewed by one pathologist (DW), while the cytological diagnoses of the original hospitals were used.

\section{Outcome parameter}

We formulated definitions of regression, no change, and progression of cervical dysplasia for those cases where there was a histological diagnosis after three months of medication (table 1A) and separate definitions for those where there was only a cytological diagnosis after three months of medication (tabe 1B). The question marks refer to a broad and a strict definition. In the broad definition even the slightest change of the dysplastic stage is regarded as regression or progression, and thus $\mathrm{R}$ ? and $\mathrm{P}$ ? are counted as regression and progression respectively. In the strict definition only the larger changes are called regression or progression, and $R$ ? and $P$ ? indicate no change. The reason for using a broad and a strict definition was that we had to account for imprecision in the histological and cytological diagnoses.

\section{Statistical analysis}

The change in degree of dysplasia was assessed after stratification on the CIN class at admittance. First the cytological and histological diagnoses at the follow-up examinations were considered separately and tested for statistical significance using a stratified Wilcoxon-Mann-Whitney test (10). Next the cytological and histological diagnoses were converted into the abovementioned definitions of regression and progression. As the number of patients who showed progression was too small to analyse separately, we decided to combine the cases which showed 'progression' and 'no change' into a group 'no regression'. In the further analysis the incidence of 'regression' was compared with 'no regression', using the Mantel-Haenszel X2 test and precision-based $95 \%$ confidence intervals (11). 
Table 1: Definitions of regression and progression."

A. Defunitions comparing histolong at admission with histology after medication.

histology histology after medication

$\begin{array}{llll}\text { at admission } & \text { no CIN } & \text { CIN I } & \text { CIN II }\end{array}$

$\begin{array}{lllll}\text { CIN I } & \text { R? } & & \text { P? } & \text { P } \\ \text { CIN II } & \text { R } & \text { R? } & & \text { P? } \\ \text { CIN III } & \text { R } & \text { R } & \text { R? } & \end{array}$

B: Definitions comparing histology at admission with cytology after medication.

histology cytology after medication

$\begin{array}{llll}\text { at admission } & \text { PAP I or II PAP IIIA PAP IIIB P IV or V }\end{array}$

CIN 1

CIN II

CIN III
$\mathrm{R}$ ?
P?

$P ? \quad P$

P? P

* $\mathrm{R}=$ regression; $\mathrm{P}=$ progression; blanks = no change; Broad definition: $\mathrm{R}$ ? and $\mathrm{P}$ ? are regarded as $\mathrm{R}$ and $P$ respectively; Strict definition: $R$ ? and $P$ ? are regarded as "no change".

After this elementary analysis, we adjusted for residual confounding. The success of randomization was checked by comparing the distribution of a number of relevant prognostic variables over the beta-carotene and placebo groups: degree of dysplasia at admission, age, marital status, number of children, number of sex partners during life, frequency of coitus, use of oral contraceptives, former use of oral contraceptives, education, smoking habits, use of vitamin $A$ and vitamin $C$ pils, and dietary intake of beta-carotene, retinol, vitamin $\mathrm{C}$ and dietary fibre. $\mathrm{A}$ logistic regression model was used to control simultaneously for the abovementioned prognostic variables. The variables were entered in the model as categorical variables using indicator terms (12). A secondary analysis was performed on the total intake of beta-carotene, estimated from the data on the dietary intake in the placebo group and by adding $10 \mathrm{mg}$, multiplied by the compliance score, to the dietary intake of the patients assigned to the beta-carotene group. In the logistic regression analysis the total intake of beta-carotene was entered as a continuous variable and adjusted for the same variables as in the first logistic regression model. The BMDP software was used for all statistical analyses (13). 


\section{Resullts}

\section{Study population}

In the years 1984-1987, 369 patients entered the trial and were randomized. Of these, 182 received beta-carotene medication and 187 received placebo medication. It turned out later that 36 patients had no histological diagnosis of dysplasia at admittance. This resulted in 333 eligible patients. In the course of the study, 55 patients (17\%) dropped out for various reasons: 23 patients sent in the reply postcard, 19 did not return for the second examination after three months, 5 received another treatment during the medication period and 8 became pregnant during the intervention period. No side effects of beta-carotene or placebo medication have been reported to us.

The number of drop-outs and the reasons for withdrawal, as well as the number of ineligible patients, were equally distributed over the beta-carotene and placebo groups. The data of the remaining 278 patients were used in the analysis, 137 assigned to the experimental group and 141 to the control group.

\section{Outcome parameter}

A histological diagnosis after the intervention period was available for 126 patients. In 152 patients, the gynaecologist did not consider a biopsy indicated. The decision to take a biopsy depends on the cytological diagnosis and/or the colposcopic appearance of the lesion. The patients for which a histological diagnosis after the medication period was available, did indeed show a more advanced degree of dysplasia. It turned out that the number of histological diagnoses was almost the same in both treatment groups: 62 cases in the beta-carotene group and 64 in the placebo group. To make the best possible use of the available information the definition of regression and progression was based on the histological diagnosis after the intervention period, if available, and on the cytological diagnosis after the intervention period otherwise.

\section{Effect of beta-carotene medication}

The data on the changes in dysplastic stage over the medication period for the two treatment groups are presented in table $2 \mathrm{~A}$ for the 126 patients who had a histological diagnosis after the intervention period and in table $2 \mathrm{~B}$ for the 152 patients for whom only a cytological diagnosis was available. The changes were not different for the group with beta-carotene and the group with placebo medication. 
Table 2A: Comparison of the histological diagnosis at admission with the histological diagnosis after medication, according to medication with beta-carotene (B) or placebo (P).

\begin{tabular}{|c|c|c|c|c|c|c|}
\hline \multirow{2}{*}{$\begin{array}{l}\text { histology } \\
\text { at admission }\end{array}$} & \multirow{2}{*}{$\begin{array}{l}\text { medi- } \\
\text { cation }\end{array}$} & \multicolumn{5}{|c|}{ histology after medication } \\
\hline & & $\begin{array}{l}\text { no abnor- } \\
\text { malities }\end{array}$ & CIN I & CIN II & CIN III & total \\
\hline $\mathrm{CIN} \mathrm{I}$ & $\begin{array}{l}\mathrm{B} \\
\mathrm{P}\end{array}$ & $\begin{array}{l}2 \\
3\end{array}$ & $\begin{array}{r}9 \\
11\end{array}$ & $\begin{array}{l}1 \\
3\end{array}$ & $\begin{array}{l}1 \\
0\end{array}$ & $\begin{array}{l}13 \\
17\end{array}$ \\
\hline $\mathrm{CIN}$ II & $\begin{array}{l}\mathrm{B} \\
\mathrm{P}\end{array}$ & $\begin{array}{l}6 \\
5\end{array}$ & $\begin{array}{l}4 \\
8\end{array}$ & $\begin{array}{l}12 \\
11\end{array}$ & $\begin{array}{l}5 \\
4\end{array}$ & $\begin{array}{l}27 \\
28\end{array}$ \\
\hline CIN III & $\begin{array}{l}B \\
P\end{array}$ & $\begin{array}{l}0 \\
2\end{array}$ & $\begin{array}{l}4 \\
2\end{array}$ & $\begin{array}{l}8 \\
6\end{array}$ & $\begin{array}{r}10 \\
9\end{array}$ & $\begin{array}{l}22 \\
19\end{array}$ \\
\hline total & $\begin{array}{l}\mathrm{B} \\
\mathrm{P}\end{array}$ & $\begin{array}{r}8 \\
10\end{array}$ & $\begin{array}{l}17 \\
21\end{array}$ & $\begin{array}{l}21 \\
20\end{array}$ & $\begin{array}{l}16 \\
13\end{array}$ & $\begin{array}{l}62 \\
64\end{array}$ \\
\hline
\end{tabular}

Stratified Wilcoxon-Mann-Whitney test: $\mathrm{Z}=0.45 ; \mathrm{p}=0.65$.

Table 2B: Comparison of the cytological diagnosis at admission with the cytological diagnosis after medication, according to medication with beta-carotene (B) or placebo (P), for patients without a histological diagnosis after medication.

\begin{tabular}{|c|c|c|c|c|c|c|}
\hline \multirow{2}{*}{$\begin{array}{l}\text { histology } \\
\text { at admission }\end{array}$} & \multirow{2}{*}{$\begin{array}{l}\text { medi- } \\
\text { cation }\end{array}$} & \multicolumn{5}{|c|}{ cytology after medication } \\
\hline & & PAP I or II & PAP IIIA & PAP IIIB & $\gtrsim$ PAP IV & total \\
\hline CIN I & $\begin{array}{l}\mathrm{B} \\
\mathrm{P}\end{array}$ & $\begin{array}{l}17 \\
15\end{array}$ & $\begin{array}{l}6 \\
9\end{array}$ & $\begin{array}{l}0 \\
0\end{array}$ & $\begin{array}{l}0 \\
0\end{array}$ & $\begin{array}{l}23 \\
24\end{array}$ \\
\hline CIN II & $\begin{array}{l}\mathrm{B} \\
\mathrm{P}\end{array}$ & $\begin{array}{l}17 \\
20\end{array}$ & $\begin{array}{l}12 \\
13\end{array}$ & $\begin{array}{l}1 \\
0\end{array}$ & $\begin{array}{l}0 \\
0\end{array}$ & $\begin{array}{l}30 \\
33\end{array}$ \\
\hline CIN III & $\begin{array}{l}\mathrm{B} \\
\mathrm{P}\end{array}$ & $\begin{array}{r}12 \\
6\end{array}$ & $\begin{array}{r}8 \\
13\end{array}$ & $\begin{array}{l}1 \\
0\end{array}$ & $\begin{array}{l}1 \\
1\end{array}$ & $\begin{array}{l}22 \\
20\end{array}$ \\
\hline total & $\begin{array}{l}\mathrm{B} \\
\mathbf{P}\end{array}$ & $\begin{array}{l}46 \\
41\end{array}$ & $\begin{array}{l}26 \\
35\end{array}$ & $\begin{array}{l}2 \\
0\end{array}$ & $\begin{array}{l}1 \\
1\end{array}$ & $\begin{array}{l}75 \\
77\end{array}$ \\
\hline
\end{tabular}

Stratified Wilcoxon-Mann-Whitney test: $\mathbf{Z}=-0.87 ; \mathrm{p}=0.38$. 
Using the definitions of regression and progression as presented in table 1, the data in table 2 can be transformed into figure 1 , depicting the effect of beta-carotene medication on the regression and progression of cervical dysplasia.

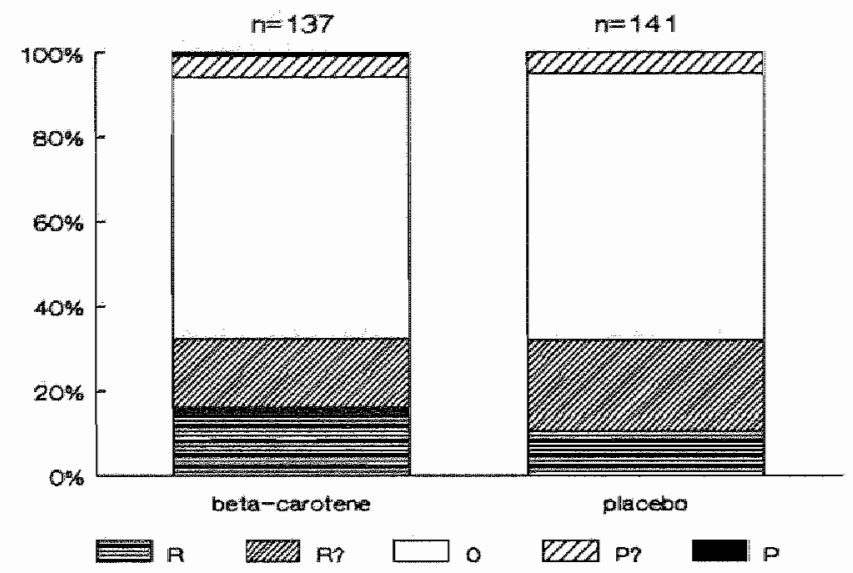

Figure 1: Percentages or regression $(\mathbb{R})$, no change $(O)$, and progression ( $P$ ) in the beta-carotene and placebo groups.

After adjustment for the degree of dysplasia at admission, almost no difference in regression percentage is seen $\left(\mathrm{OR}_{\mathrm{MH}}=0.83 ; 95 \% \mathrm{CI}: 0.44\right.$ to 1.58$)$, if one uses the broad definition (table $3 \mathrm{~A}$ ).

Using the strict definition (table 3B), a slightly higher percentage of regression is seen in the beta-carotene group, but the percentage is not statistically significantly different from the placebo group $\left(\mathrm{OR}_{\mathrm{MH}}=1.52 ; 95 \% \mathrm{CI}: 0.71\right.$ to 3.21$)$. Note that the numbers of patients who showed progression were very small in both treatment groups, but these did not seem to differ between the treatment groups either.

\section{Success of randomization}

To avoid an unequal distribution of important prognostic variables over the two treatment groups, we stratified before randomization on the hospital from which the patients were entered into the study, on the degree of dysplasia and on the age of the patients. 
Table 3A: Regression and progression using the broad defintion for beta-carotene (B) ata placebo (P) medication, according to the histological diagnosis at admission.

\begin{tabular}{llllll}
\hline $\begin{array}{l}\text { histology } \\
\text { at admission }\end{array}$ & $\begin{array}{l}\text { medi- } \\
\text { cation }\end{array}$ & regression & no change & progression & total \\
\hline CIN I & B & $2(6 \%)$ & $32(89 \%)$ & $2(6 \%)$ & 36 \\
& P & $3(7 \%)$ & $35(85 \%)$ & $3(7 \%)$ & 41 \\
CIN II & B & $10(18 \%)$ & $41(72 \%)$ & $6(11 \%)$ & 57 \\
& P & $13(21 \%)$ & $44(72 \%)$ & $4(7 \%)$ & 61 \\
CIN III & B & $32(73 \%)$ & $12(27 \%)$ & $0(0 \%)$ & 44 \\
& P & $29(74 \%)$ & $10(26 \%)$ & $0(0 \%)$ & 39 \\
\cline { 2 - 6 } & $\mathrm{B}$ & $44(32 \%)$ & $85(62 \%)$ & $8(6 \%)$ & 137 \\
& $\mathrm{P}$ & $45(32 \%)$ & $89(63 \%)$ & $7(5 \%)$ & 141 \\
\hline
\end{tabular}

$\mathrm{OR}_{\mathrm{MH}}=0.83 ; \mathrm{x}_{\mathrm{MH}}^{2}=0.17 ; \mathrm{p}=0.68$.

Table 3B: Regression and progression using the strict definition for beta-carotene (B) and placebo (P) medication according to the histological diagnosis at admission.

\begin{tabular}{|c|c|c|c|c|c|}
\hline $\begin{array}{l}\text { histology } \\
\text { at admission }\end{array}$ & $\begin{array}{l}\text { medi- } \\
\text { cation }\end{array}$ & regression & no change & progression & total \\
\hline CIN I & $\begin{array}{l}\mathrm{B} \\
\mathrm{P}\end{array}$ & $\begin{array}{l}0(0 \%) \\
0(0 \%)\end{array}$ & $\begin{array}{l}35(97 \%) \\
41(100 \%)\end{array}$ & $\begin{array}{l}1(3 \%) \\
0(0 \%)\end{array}$ & $\begin{array}{l}35 \\
41\end{array}$ \\
\hline CIN II & $\begin{array}{l}\mathrm{B} \\
\mathrm{P}\end{array}$ & $\begin{array}{l}6(11 \%) \\
5(8 \%)\end{array}$ & $\begin{array}{l}51(89 \%) \\
56(92 \%)\end{array}$ & $\begin{array}{l}0(0 \%) \\
0(0 \%)\end{array}$ & $\begin{array}{l}57 \\
61\end{array}$ \\
\hline CIN III & $\begin{array}{l}\mathrm{B} \\
\mathrm{P}\end{array}$ & $\begin{array}{l}16(36 \%) \\
10(26 \%)\end{array}$ & $\begin{array}{l}28(64 \%) \\
29(74 \%)\end{array}$ & $\begin{array}{l}0(0 \%) \\
0(0 \%)\end{array}$ & $\begin{array}{l}44 \\
39\end{array}$ \\
\hline total & $\begin{array}{l}\mathrm{B} \\
\mathrm{P}\end{array}$ & $\begin{array}{l}22(16 \%) \\
15(11 \%)\end{array}$ & $\begin{array}{l}114(83 \%) \\
126(89 \%)\end{array}$ & $\begin{array}{l}\text { 1. }(1 \% \%) \\
0(0 \%)\end{array}$ & $\begin{array}{l}137 \\
141\end{array}$ \\
\hline
\end{tabular}

$\mathrm{OR}_{\mathrm{MH}}=1.52 ; \mathrm{x}_{\mathrm{MH}}^{2}=0.82 ; \mathrm{p}=0.36$. 
Table 4 presents the frequency distribution of potential prognostic variables over the beta-carotene and placebo groups. Most of these variables were assessed by the questionnaire. As 31 of the 278 patients involved in the analysis did not return their questionnaire (16 patients in the beta-carotene group and 15 patients in the placebo group) and some patients had failed to answer particular questions, the number of patients for whom information was available was somewhat lower than 247 for most variables.

Table 4: Frequency distribution of categories of potential prognostic variables.

\begin{tabular}{lll}
\hline Variable & $\begin{array}{ll}\text { beta-carotene } \\
n=137 \\
\%\end{array}$ & $\begin{array}{l}\text { placebo } \\
\%=141 \\
\end{array}$ \\
\hline
\end{tabular}

Histology at admission

CIN I

CIN II

CIN III

Age

$$
\leq 25
$$

26-30

$31-35$

$36-40$

$>40$

Marital status

unmarried

living together

manried

divorced or widowed

Number of children

$$
\begin{array}{r}
0 \\
1.2 \\
\times 3
\end{array}
$$

Number of sex partners

$$
\begin{array}{r}
1 \\
2-3 \\
4-5 \\
26
\end{array}
$$

Frequency of coitus

$$
>3 \text { per week }
$$


Use of any contraceptives

Use of orall contraceptives

Former use of oral

contraceptives

Female sterilization

Education

low

middle

high

Smoking habits

smoker

n.r. of cigarettes/day $>20$

ex-smoker

Use of vitamin A pills

Use of vitamin C pills

Beta-carotene intake (mg)

$\leq 1.5$

1.5-2.5

2.5-3.5

$>3.5$

Retinol intake (mg)

$\leq 0.3$

0.3-0.4

$0.4-0.5$

$>0.5$

Vitamin C intake (mg)

$\leq 50$

50- 75

$75-100$

$>100$

Dietary fibre intake (g)

$\leq 10$

10-15

$15-20$

$>20$
59

40

57

17

44

19

37

50

13

32

55

13

72

37

17

16

16

68

28

15

8

21

33

22

26

22

18

23

27

29

27

30

17

26

24

21

22

33

31

19

19

31

22

22

19

37

$30 \quad 16$

$33 \quad 32$

$27 \quad 32$

$10 \quad 20$

The mean dietary intake of beta-carotene was $2.4 \mathrm{mg}$ in the beta-carotene group and 3.1. $\mathrm{mg}$ in the placebo group. This means that, by chance, the contrast in beta-carotene intake between the beta-carotene and placebo group was slightly less than $10 \mathrm{mg}$. 
Adjustment for prognostic variables

All variäbles mentioned in table 4 were entered simultaneously in a logistic regression model. The point estimate of the effect of beta-carotene on regression of cervicall dysplasia chariged from $\mathrm{OR}=0.83(95 \% \mathrm{Cl}: 0.44$ to 1.58$)$ to $\mathrm{OR}=0.68(95 \% \mathrm{Cl}: 0.28$ to 1.60$)$ using the broad definition and from $\mathrm{OR}=1.52(95 \% \mathrm{CI}: 0.71$ to 3.21$)$ to $\mathrm{OR}$ $=1.22$ (95\% Cl: 0.43 to 3.41$)$ using the strict definition.

\section{Time between the gynaecological examinations}

The patients each received 100 capsules, which was amply sufficient for three months of medication. However, it turned out that many patients appeared at the control visit after a little more than three months, i.e. at a time when medication had already stopped, given good compliance. The median time between the two examinations was 110 days. To check whether a possible effect would disappear by stopping the medication (rebound effect), we studied the effect of beta-carotene separately for patients assumed to be still on medication and for patients assumed to have stopped medication. In both situations no effect of beta-carotene could be observed.

\section{Effect of the total beta-carotene intake}

We estimated the total intake of beta-carotene for every patient by using the dietary intake of beta-carotene for the placebo group and by adding $10 \mathrm{mg}$ multiplied by the compliance score for the patients assigned to the beta-carotene group. Data on compliance, as assessed by pill counts and by patients' reports, are presented in table 5 , together with the assigned compliance scores.

Table 5: Compliance measurements: inquiry by questionnaire versus pill counts, with the assigned compliance score in brackets.

number of times per week forgotten according to the questionnaire

pillis re-

turned

$$
0
$$

1

2

3

7

uriknown total

\begin{tabular}{lccccccc}
\hline 0 & $109(1.0)$ & $53(0.85)$ & $5(0.7)$ & $1(0.5)$ & 0 & $8(1.0)$ & 1.76 \\
$1-10$ & $33(0.9)$ & $20(0.85)$ & $1(0.7)$ & $2(0.5)$ & 0 & $4(0.9)$ & 60 \\
11.20 & 0 & $8(0.80)$ & $2(0.7)$ & 0 & 0 & $3(0.8)$ & 13 \\
21.50 & 0 & 0 & $3(0.5)$ & 0 & 0 & $5(0.5)$ & 8 \\
51.540 & 0 & 2 & 0 & 0 & 0 & $2(0.1)$ & 4 \\
91.100 & 0 & 0 & 0 & 0 & $1(0)$ & $4(0.0)$ & 5 \\
unknown & $2(1.0)$ & 0 & $1(0.7)$ & 0 & 0 & $9(0.1)$ & 12 \\
\hline & 144 & 83 & 12 & 3 & 1 & 35 & 278 \\
\hline
\end{tabular}


If both parameters were missing, a compliance score of 0.1 was applied. The total intake of beta-carotene in the study population had a bimodal distribution with a dip at about $7.5 \mathrm{mg}$ (figure 2).

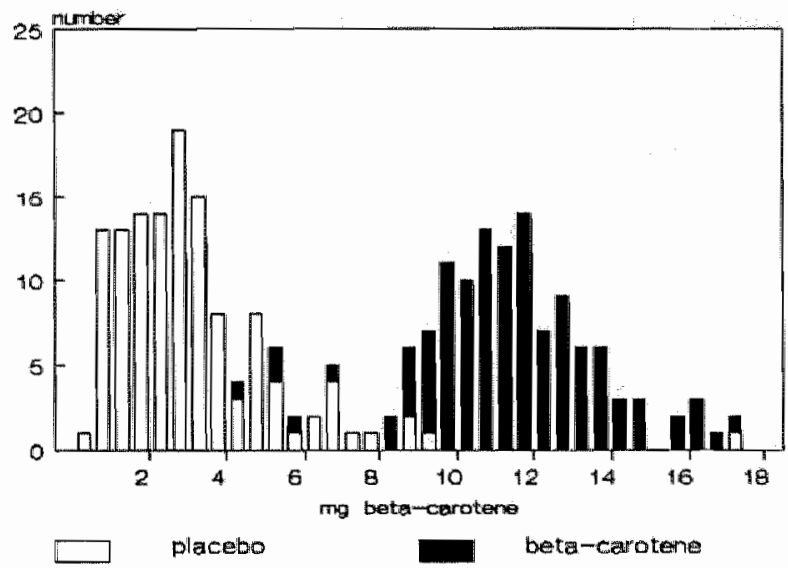

Figure 2: Distribution of total daily intake of beta-carotene in the study population.

The unadjusted effect of the total beta-carotene intake on the regression and progression of cervical dysplasia is depicted in figure 3 .

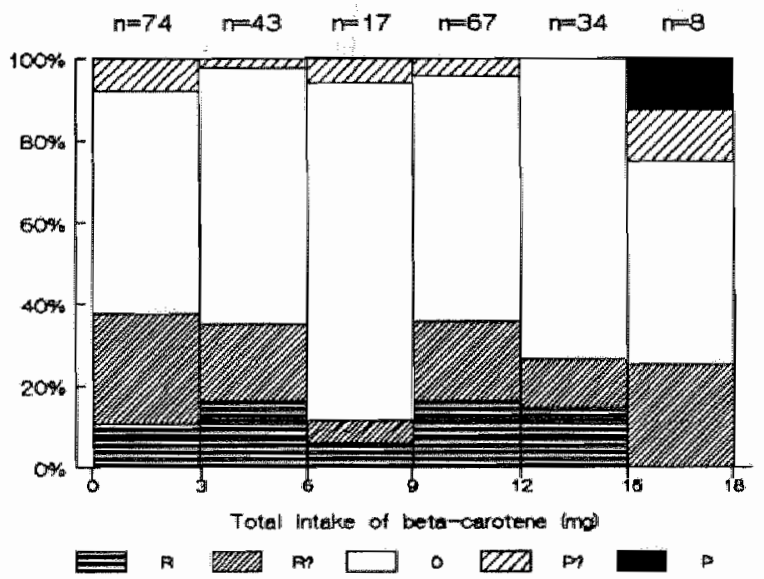

Figure 3: Percentages of regression $(R)$, no change $(O)$ and progression $(P)$ in various categories of beta-carotene intake. 
The regression percentages in the categories with a high intake of beta-carotene did not differ from those in the categories with a low intake. In the range of $0-6 \mathrm{mg}$ beta-carotene we did not observe differences in regression percentages either. This range of intakes is of importance in non-experimental epidemiological studies, in which the class with the highest dietary intake of beta-carotene is compared with the class with the lowest dietary intake.

After adjustment for all prognostic variables mentioned in table 4 , the patients with a high beta-carotene intake showed almost identical regression percentages compared to the patients with a low beta-carotene intake (e.g. $12 \mathrm{mg}$ vs. $3 \mathrm{mg}$, corresponding to the modes in figure 2): $\mathrm{OR}=0.75$ (95\% Cl: 0.43 to 1.48 ) using the broad definition and $\mathrm{OR}=1.15(95 \% \mathrm{Cl}: 0.57$ to 2.29$)$ using the strict definition.

\section{Discussion}

The data were analyzed in two ways. In the main analysis all patients assigned to the beta-carotene group were compared to all patients assigned to the placebo group, on condition that the patients were eligible for the trial and the outcome parameter could be assessed. However, the total intake of beta-carotene varied considerably in the study population, either because some patients had a poor compliance, or due to the variations in dietary intake. We therefore decided also to perform an analysis according to the amount of beta-carotene that the patients actually consumed. This secondary analysis made the best possible use of the available information. Both ways of analysis yielded comparable results. Using the broad definition slightly less regression and using the strict definition slightly more regression was observed for the patients with the highest beta-carotene intake. None of these differences were large and they did not reach statistical significance. Therefore, our main conclusion is that an extra dose of 10 $\mathrm{mg}$ beta-carotene per day for three months has no detectable effect on the regression and progression of cervical dysplasia.

A number of critical decisions were taken in our study design which may have affected the results, such as the biopsy before admission, the outcome parameter, the duration of the intervention period, the dose of beta-carotene, the compliance, and the number of patients. The impact of each of these factors on our study results will be discussed below.

\section{Biopsy before entry into the trial}

An important decision to be taken was whether we required a histological or cytological diagnosis before admission to the trial. A histological diagnosis is regarded as more valid than a cytological diagnosis, but on the other hand a biopsy itself is said to induce regression, either by removing (part of) the lesion, or as a consequence of the healing reaction after a biopsy is taken (14). Nowadays almost all gynaecologists require a histological diagnosis when the cytological diagnosis indicates a dysplastic stage. Therefore, an experiment based on only cytological diagnoses would have been 
unacceptable for them. We instructed the participating gynaecologists to perform a diagnostic punch biopsy, in order to minimize the chance of removing the complete lesion or inducing regression. It is impossible to indicate to what extent the biopsies have led to regression in our study. But there is a chance that the biopsy caused part of the regression and thus left beta-carotene less of an opportunity to exert an effect. Although this does not affect the validity of our experiment, it may have reduced the efficiency to some extent.

\section{Precision of the outcome-parameter}

It is known that intra- and interobserver variation occurs in the assessment of pathological slides. Four pathologists assessed 106 histological slides involved in our experiment and showed considerable interobserver disagreement. Similar results have been found in other studies, which distinguished comparable grades of dysplasia $(15,16)$. Thus it is obvious that our outcome parameter, which is based on two pathological diagnoses (either two histological diagnoses or a histological and a cytological diagnosis) is plagued by some imprecision. We have tried to minimize this imprecision by revising all the pathological slides. One pathologist (DW) blindly assessed all the histological slides. If his diagnosis corresponded with that of the original hospital, that diagnosis was used in the outcome parameter. If his diagnosis differed, he reexamined the slide without knowledge of the previous diagnoses. The diagnosis with which this second diagnosis corresponded, either that of the original hospital or his own first diagnosis, was used in the outcome parameter. All cytological diagnoses were revised by four cytologists of the Department of Pathology of the University Hospital Maastricht, using the same procedure to come to a final diagnosis. It turned out that only $10 \%$ of the cytological diagnoses changed after revision, compared to $25 \%$ of the histological diagnoses. As the cytologists are getting used to the staining pattern of their own hospital, the cytological diagnoses of the original hospitals are probably more valid than the revised ones. Therefore it was decided to base the outcome parameters on the revised histological diagnoses and on the original cytological diagnoses. But even with these efforts, some imprecision has probably remained. As it is impossible to state the degree of imprecision of the outcome parameter, it is difficult to decide which of the definitions of regression and progression is the best one to apply. Therefore, both were presented in the results section. However, if beta-carotene has a minor effect on the regression and progression of cervical dysplasia, it may have been masked by the imprecision in our outcome parameter.

\section{Duration of the intervention period}

A period of three months without treating a patient with cervical dysplasia was the maximum period acceptable for the participating gynaecologists, especially since effective and not very radical therapies, such as cryocoagulation and laser therapy, are now available. The question is whether an effect of beta-carotene on regression and progression of dysplasia, if present, is observable within three months. Such a term is not unrealistic, as the portio epithelium is completely replaced by a new population of 
cells every 4 to 5 days (17). Moreover, beta-carotene reaches the tissues within a few weeks, although considerable interindividual variation exists (18). Our confidence that the three months period was long enough to observe an effect was based on experimental studies with retinoids, synthetic derivates of retinol. These trials showed regression of precancerous lesions of skin, oral mucosa and cervical tissue within three months (19). However, it is unknown whether beta-carotene exerts its effect as betacarotene or after conversion into retinol. If the beta-carotene mechanism of cancer prevention differs from the retinoid mechanism, it is not certain whether a period of three months was long enough.

\section{Dose of beta-carotene}

A dose of $10 \mathrm{mg}$ beta-carotene was chosen because it needed to be high enough to ensure that there was a considerable contrast between the beta-carotene and placebo groups, and low enough to prevent yellowing of the skin. The mean dietary intake of beta-carotene in the Netherlands is $2-3 \mathrm{mg}$ per day (20). Our study found a similar mean dietary intake of beta-carotene, and only one of our participants, assigned to the placebo group, had a dietary intake of more than $10 \mathrm{mg}$ per day. Thus a clear contrast in total intake of beta-carotene was obtained.

Non-experimental studies do not suggest that megadoses are required for a cancer preventive effect. In most case-control and cohort studies relations were found while persons with the highest carotene intake were consuming far less than $10 \mathrm{mg}$ a day. In our experiment not even a tendency towards a higher regression percentage could be observed for the group with the highest beta-carotene intake (figure 3 ). This makes it improbable that the dose was too low.

\section{Compliance}

To increase the compliance we made it easy for the patients to withdraw from the study. They just had to send in a reply postcard. Adjusting for compliance by a compliance score did not change the results. It has to be emphasized, however, that the validity of the measurements is unknown, as patients who showed complete compliance according to our measures could have cheated on both parameters.

\section{Number of patients}

From the beginning of the experiment it was anticipated that the effect of beta-carotene on the progression of cervical dysplasia could not be studied. As the progression rate is low, a very large number of patients would have been required to detect a potential difference between the beta-carotene and placebo groups.

We have tried to collect information from the literature about the regression percentages that we could expect under our conditions: a biopsy at entry, a follow-up period of three months and a group of patients with various degrees of dysplasia. However, the literature about this subject is confusing because the studies vary in their definitions of regression and progression, in the degree of dysplasia of the patients 
involved, and in the duration of follow-up periods. Moreover, a mix of cytological and histological diagnoses is used.

We aimed at about $350-400$ patients. Of the 369 patients that were randomized, 333 patients were eligible, and 278 patients were suitable for analysis. Based on an observed regression percentage of $32 \%$ in the control group by using the broad definition, at $50 \%$ increase in the beta-carotene group would have been detectable at $\alpha$ (one-sidedi) $=0.01$ and power $(1-B)>0.90$. Using the strict definition with 278 patients, a $50 \%$ increase in regression percentage from $16 \%$ to $24 \%$ would have been detectable at $\alpha$ (one-sided) $=$ 0.05 and power $(1-B)>0.80$. Thus the number of patients in our trial does not appear to be too small to detect an effect of beta-carotene if it had occurred in our situation.

Having reviewed a number of critical issues, we feel that only the biopsy, the choice of the outcome parameter, and the duration of the intervention period could possibly have masked a potential effect. Unfortunately it is impossible to estimate the impact of these factors, separately and/or in combination. But as no effect at all was observed in our study we consider it to be unlikely that beta-carotene has a large effect on the regression of cervical dysplasia.

If beta-carotene had shown a favorable effect on the regression (or progression) of cervical dysplasia, it would have been consistent with the results of non-experimenta] studies and would thus have yielded extra evidence for a causal relation between beta-carotene and cancer.

Now that an experimental study has shown no effect on the regression (and progession) of cervical dysplasia, a causal relation will have to be rejected, or other explanations will have to be put forward.

Alternative explanations may be found in the operationalization of the primary question, whether beta-carotene protects against cancer, into the research question whether beta-carotene has any influence on cervical dysplasia. This operationalization implies choosing a specific stage of the cancer process and a specific type of cancer. In order to answer the question which stage of the cancer process is influenced by beta-carotene, a closer look at the mechanism of the effect is required. There is an ongoing discussion whether beta-carotene exerts its effect after conversion into retinol or as a carotenoid as such. Studies undertaken to answer this question have led to the conclusion that some cancer preventive effects are exerted by carotenoids which cannot be converted into retinol, while other anticancer effects are only observed for carotenoids that can be converted into retinol, suggesting that retinol exerts the ultimate effect $(21,22)$. Unfortunately, it is unknown which mechanism is involved in the prevention of human carcinogenesis. Therefore, evidence for beta-carotene as well as for retinol will be discussed in order to answer the question whether beta-carotene is able to affect this stage of the cancer process. For both beta-carotene and retinol, cancer preventive mechanisms are known (23,24). Moreover, cancer preventive effects in the promotional phase of the cancer process have been observed for both $(19,25)$. It is uncertain, however, whether precancerous stages in humans correspond with the 
promotional phases in experimental carcinogenesis. For retinoids, preventive effects on precancerous stages of skin cancer and oral cancer, and on the recurrence of bladder cancer have been observed in randomized trials in humans (19). For carotenoids, several randomized studies are in progress, but not yet published.

Thus there are some indications, but no convincing evidence, that carotenoids influence this late phase of the cancer process. Therefore, one explanation for our results may be that beta-carotene only affects the early phases of the cancer process.

Another explanation may be that beta-carotene does not affect cervical cancer. Kinetic studies with beta-carotene in rats have shown that beta-carotene levels differ considerably between various tissues (26). Data on the beta-carotene content of cervical tissue are not available. It is possible that beta-carotene does not reach the cervical tissue. However, non-experimental studies on beta-carotene and cancer do not suggest that cervical cancer is an exception.

Future randomized trials with beta-carotene studying other stages of the cancer process or other cancer locations will show whether our results were due to the choice of cervical cancer, to the stage of the cancer process that we studied, to invalidities in our study design or simply to the fact that beta-carotene does not protect against cancer after all. 


\section{References}

1. Byers T, Graham S. The epidemiology of diet and cancer. Adv. Cancer Res 1984; 11: $1-68$.

2. Willett WC, MacMahon B. Diet and cancer - an overview. New Engl J Med 1984; 30: 633-638.

3. Peto R, Doll R, Buckley JD, Sporn MB. Can dietary beta-carotene materially reduce human cancer rates? Nature 1981; 290: 201-208.

4. Vet HCW de. The puzzling role of vitamin $\mathrm{A}$ in cancer prevention (Review). Anticancer Res 1989; 9: 145-151.

5. Romney SL, Palan PR, Duttagupta $\mathrm{C}_{\text {, }}$ et al. Retinoids and the prevention of cervical dysplasias. Am J Obstet Gynecol 1981; 141: 890-894.

6. Marshall JR, Graham S, Byers T, Swanson M, Brasure J. Diet and smoking in the epidemiology of cancer of the cervix. J Natl Cancer Inst 1983; 70: 847-851.

7. LaVecchia C, Franceschi S, Decarli A, et al. Dietary vitamin A and the risk of invasive cervical cancer. Int J Cancer 1984; 34: 319-322.

8. Bernstein A, Harris $B$. The relationship of dietary and serum vitamin $A$ to the accurrence of cervical intraepithelial neoplasia in sexually active women. Am J Obstet Gynecol 1984; 148: 309-312.

9. Richart RM. Natural history of cervical intraepithelial neoplasia. Clin Obstet Gynecol 1967; 10: 748-784.

10. Lehmann EL. Nonparametrics. Statistical Methods Based on Ranks. San Francisco: Holden Day Inc, New York: McGraw-Hill, International Book Company, 1975.

11. Kleinbaum DG, Kupper LL, Morgenstern H. Epidemiological Research. Principles and quantitative methods. London: Lifetime Learning Publications, 1982.

12. Rothman KJ. Modern Epidemiology. Boston, Toronto: Little Brown and Company, 1986.

13. Dixon WJ (ed.). BMDP Statistical Software. Berkeley, Los Angeles, London: University of California Press, 1985.

14. Koss LG, Stewart FW, Foote FW, Jordan MJ, Bader GM, Day E. Some histological aspects of behavior of epidermoid carcinoma in situ and related lesions of the uterine cervix. A long term prospective study. Cancer 1963; 16: 1160-1211.

15. Ismail SM, Colclough AB, Dinnen JS, et al. Observer variation in histopathological diagnosis and grading of cervical intraepithelial neoplasia. Br Med J 1989; 298: $707-710$.

16. Robertson AJ, Anderson JM, Swanson Beck J, et al. Observer variability in histopathological reporting of cervical biopsy specimens. J Clin Pathol 1989; 42: 231-238.

17. Ferenczy A. Cervical intra-epithelial neoplasia. In: Pathology of the female genital tract. Blaustein A. ed. New York, Heidelberg, Berlin: Springer Verlag 1977, p. 143-165.

18. Dimitrov NV, Meyer C, Ulirey DE, et al. Bioavailability of beta-carotene in humans. Am J Clin Nutr 1988; 48: 298-304. 
19. Lippmann SM, Kessler JF, Meyskens FL. Retinoids as preventive and therapeutic anticancer agents (part II). Cancer Treat Rep 1987; 71: 493-515.

20. Hartog C den, Schaik ThFSM van, Dalderup LM, Drion EF, Mulder T. The diet of volunteers participating in a long term epidemiological field survey on coronary heart disease at Zutphen, the Netherlands. Voeding 1965; 26: 184-208.

21. Mathews-Roth MM. Antitumor activity of beta-carotene, canthaxanthin and phytoene. Oncology 1982; 39: 33-37.

22. Stich HF, Stich W, Rosin MP, Vallejera MO. Use of the micronucleus test to monitor the effect of vitamin $A$, beta-carotene and canthaxanthin on the buccal mucosa of betelnut/tobacco chewers. Int J Cancer 1984; 34: 745-750.

23. Wolf G. Multiple functions of vitamin A. Physiol Rev 1984; 64: 873-937.

24. Sporn MB, Roberts $A B$. Role of retinoids in differentiation and carcinogenesis. Cancer Res 1983; 43: 3034-3040.

25. Mathews-Roth MM. Carotenoids and cancer prevention. Experimental and epidemiological studies. Pure \& Appl Chem 1985; 57: 717-722.

26. Shapiro SS, Mott DJ, Machlin LJ. Kinetic characteristics of beta-carotene uptake and depletion in rat tissue. $J$ Nutr $1984 ; 114: 1924-1933$. 
Chapter 6

\section{INTEROBSERVER VARIATION IN HISTOPATHOLOGICAL GRADING OF CERVICAL DYSPLASIA.*}

Henrica C.W. de Vet ${ }^{1}$, Paul G. Knipschild, Hubert J.A. Schouten ${ }^{2}$, Johan Koudstaal ${ }^{3}$, Wie-sien Kwee ${ }^{4}$, Dirk Willebrand 5 , Ferd Sturmans ${ }^{1}$, Jan Willem Arends 5

1 Department of Epidemiology/Health Care Research and

2 Department of Medical Informatics and Statistics, University of Limburg, Maastricht;

3 Department of Pathology, 'De Wever' Hospital, Heerlen;

4 Department of Pathology, 'St. Laurentius' Hospital, Roermond;

5 Department of Pathology, University of Limburg, Maastricht, the Netherlands

* Accepted for publication in J Clin Epidemiol 


\begin{abstract}
In order to assess the variability among histopathologists in grading cervical dysplasia, four experienced histopathologists examined the same set of 106 biopsy specimens and assigned them to one of five diagnostic categories. These were: no dysplasia, mild dysplasia, moderate dysplasia, severe dysplasia and carcinoma in situ. The histopathologists did not discuss the grading criteria beforehand. There was considerable disagreement among the pathologists: unweighted group kappa 0.28, weighted group kappa 0.56. It appeared that all grades of dysplasia were equally difficult to distinguish from adjacent categories. Various explanations for this interobserver variation are put forward.
\end{abstract}




\section{Introduction}

Pathologists play an important role in the diagnosis of cancer. Their histopathological assessments are often used as a 'gold standard'. In the diagnosis of cervical dysplasia it is customary to distinguish various grades. However, pathologists are known to differ in their interpretation of biopsy specimens (1-4).

This study aimed to assess the extent and seriousness of the disagreement in grading cervical dysplasia and to determine which grades are most difficult to distinguish.

\section{Materials and methods}

Four pathologists, two of them working at the same department, examined 106 biopsy specimens obtained from four different hospitals. The slides were used in a multicenter trial to assess the effect of beta-carotene on the regression and progression of cervical dysplasia. The pathologists used their own criteria to classify the slides into an ordinal scale of five categories: no dysplasia; mild dysplasia; moderate dysplasia; severe dysplasia; carcinoma in situ (c.i.s.). They were all professionally involved in routine diagnostic histopathology and had considerable experience in diagnosing cervical dysplasia.

The interobserver variation was assessed by calculation of kappa statistics (5). Kappa is a parameter of agreement, which takes chance agreement into account. Kappa values range from -1 to 1 , with 0 representing only chance agreement. Positive values show certain agreement beyond chance agreement. The more kappa approximates 1, the better the agreement. In addition to unweighted kappa values, weighted kappa values were calculated, using quadratic disagreement weights. This parameter is based on the idea that if two observers differ by more than one category, then their disagremeent should be given more weight than if they differ by only one category.

Besides calculations of kappa values between pairs of observers, we also calculated a group kappa. In the group kappa coefficient, the average observed agreement is compared to the average chance agreement, with the average taken over all pairs of observers and over all slides. Both an unweighted and a weighted group kappa were calculated, with their $95 \%$ confidence intervals $(\mathrm{CI})(6)$.

\section{Results}

Out of the total number of 424 assessments (106 slides $\times 4$ pathologists), 423 diagnoses were noted, as pathologist $C$ felt unable to assign one biopsy specimen to one of the five categories. Table 1 shows the frequency distributions of these scores over the various categories for the four pathologists. 
Table 1: Frequency distributions of the gradings of the four pathologists.

\begin{tabular}{llllll}
\hline & \multicolumn{1}{c}{ dysplasia } & & & c.is. \\
\cline { 2 - 5 } pathologists & no & mild & moderate & severe & \\
\hline & & & & & \\
A & $3 \%$ & $24 \%$ & $41 \%$ & $28 \%$ & $5 \%$ \\
B & $5 \%$ & $32 \%$ & $32 \%$ & $29 \%$ & $2 \%$ \\
D & $7 \%$ & $25 \%$ & $49 \%$ & $18 \%$ & $2 \%$ \\
& $2 \%$ & $25 \%$ & $29 \%$ & $36 \%$ & $9 \%$ \\
\hline
\end{tabular}

Most of the slides were categorized as mild, moderate or severe dysplasia, while in some slides no dysplastic lesions were observed and some slides were graded as carcinoma in situ.

In order to compare the agreement among individual pathologists, unweighted and weighted kappa values for each pair of observers have been collected in table 2 .

Table 2: Kappa values for agreement between pairs of pathologists using five categories of classification. Unweighted kappa values botlom left, weighted kappa values top right.

\begin{tabular}{lllll} 
Pathologists & A & B & C & D \\
\hline A & & 0.42 & 0.65 & 0.54 \\
B & 0.28 & & 0.54 & 0.51 \\
C & 0.38 & 0.18 & & 0.67 \\
D & 0.34 & 0.21 & 0.28 &
\end{tabular}

unweighted group kappa $=0.28 ; 95 \% \mathrm{Cl}:<0.21-0.36>$; weighted group kappa $=0.56 ; 95 \% \mathrm{CI}$ : $<0.46-0.66>$.

Unweighted kappa values ranged from 0.18 to 0.38 , weighted kappa values from 0.42 to 0.67. Some pathologists appeared to agree with each other more often than others. Pathologists A and B, who worked in the same department, did not show more agreement with each other than with colleagues from the other hospitals.

The unweighted group kappa was 0.28 (95\% CI: $0.21-0.36$ ). The weighted kappa was 0.56 (95\% CI: $0.46-0.66)$.

In order to assess which categories are most difficult to distinguish, the extent and seriousness of disagreement in grading cervical dysplasia are shown in table 3 . The second column from the left shows the combined frequency distribution of the scores of 
four pathologists $(n=423)$. The rows show the frequency distribution of the other three pathologists, when one pathologist assigned the score mentioned in the left-hand column. For instance, for the slides that were scored as moderate dysplasia by one pathologist, the distribution of the others was: $1 \%$ no dysplasia, $21 \%$ mild dysplasia, $50 \%$ moderate dysplasia, $26 \%$ severe dysplasia and $2 \%$ c.lis.

Table 3: Frequency distribution (\%) of the scores of three pathologists on 106 slides, conditional on the judgement of the other pathologist.

Total number

of scores

dysplasia

cilis. $n=423$

no milo moderate severe

$\begin{array}{lrrrrrr}\text { No dysplasia } & 17 & 35 \% & 47 \% & 12 \% & 6 \% & 0 \% \\ \text { Mild dysplasia } & 111 & 7 \% & 54 \% & 30 \% & 8 \% & 1 \% \\ \text { Moderate dysplasia } & 159 & 1 \% & 21 \% & 50 \% & 26 \% & 2 \% \\ \text { Severe dysplasia } & 118 & 1 \% & 7 \% & 35 \% & 49 \% & 8 \% \\ \text { C.i.s. } & 18 & 0 \% & 6 \% & 19 \% & 54 \% & 22 \%\end{array}$

It appeared that all grades were equally difficult to distinguish from their neighbours, e.g. mild and moderate dysplasia were confused as frequently as moderate and severe dysplasia. Even differences over more than one grade occurred regularly.

\section{Discussion}

Considerable disagreement was found when four experienced pathologists graded cervical biopsy specimens into five categories varying from no dysplasia to carcinoma in situ. Some pairs of pathologists showed more agreement than others, but, as had also been observed in another study (1), this was not related to working in the same department.

Kappa is the measure of choice to assess interobserver variation. It corrects for chance agreement, which is not taken into account if percentages of agreement between observers are compared. Kappa was originally designed for interobserver variation when classifying in nominal categories (5), but was later also applied to ordinal scales. This led to the development of weighted kappa (7), which takes into account the degree to which disagreement concerns adjacent or more remote categories. The unweighted kappa values depend on the number of categories one wants to distinguish on an ordinal scale: if detailed subdivisions are required, the task becomes more difficult and the kappa values will be lower (6). This entails that adequate comparison with other studies can only be made if similar categories of grading are used. A number of 
interobserver studies have been performed in which similar grades of dysplasia and c.i.s. were distinguished or which used the CIN classification. In this classification CIN III includes both severe dysplasia and c.is.s, CIN II corresponds to moderate dysplasia and CIN I to mild dysplasia. The unweighted kappa values which were presented $(3,4)$ or which could be calculated from the published data $(1,2)$ were comparable to ours. Weighted kappa values were not calculated in these studies.

In order to interpret the kappa values similar appraisal criteria were proposed for unweighted and weighted kappas $(8,9)$ : kappa values below 0.40 may be taken to represent poor agreement, values between 0.40 and 0.75 fair to good agreement, and values above 0.75 excellent agreement.

These are very arbitrary criteria, bearing in mind that unweighted kappas depend on the number of categories and weighted kappas are strongly influenced by the disagreement weights applied.

Using these appraisal criteria, the unweighted kappas would suggest poor agreement between pathologists in our study and the weighted kappas fair to good agreement. In our opinion, unweighted and weighted kappas are useful summary parameters to assess interobserver variation, but the data presented in table 3 are far more illustrative of the frequency and extent of disagreement.

It is obvious that pathologists disagree considerably in the grading of cervical dysplasia. Various explanations for this disagreement can be put forward. Grading is hampered by the arbitrary division into distinct categories of a continuously progressing process without naturally and sharply defined borders. Moreover, the criteria for grading are equivocal. With regard to histological grading, both the degree of cellular atypia and the proportion of the mucosal layer occupied by immature cells are taken into account. The ultimate diagnosis depends on the emphasis which is put on each of these characteristics in grading. Thus, the variability in diagnosis depends on which characteristics are considered to be important for the diagnosis, on the variability in the observation of these characteristics and on the variability in the grading of these characteristics into the various categories of cervical dysplasia.

We are currently conducting a study in which we have first agreed upon the relative importance of the various characteristics. Next we try to find out whether it is the observation of these characteristics or the grading of these observations into the arbitrary categories of dysplasia which is the most important source of variation. 


\section{References}

1. Pieters WJLM. The atypical mitosis as a characteristic in classifying squamous lesions of the uterine cervix. Dissertation, University of Groningen, 1987: 68-82.

2. Robertson AJ, Anderson JM, Swanson Beck J, et al. Observer variability in histopathological reporting of cervical biopsy specimens. J Clin Pathol 1989; 42: 231-238.

3. Ringsted J, Amtrup F, Asklund C, et al. Reliability of histo-pathological diagnosis of squamous epithelial changes of the uterine cervix. Acta Path Microbiol Scand Sect A $1978 ; 86: 273-278$.

4. Ismail SM, Colclough $\mathrm{AB}$, Dinnen JS, et al. Observer variation in histopathological diagnosis and grading of cervical intraepithelial neoplasia. $\mathrm{Br}$ Med J 1989; 298: 707-710.

5. Cohen J. A coefficient of agreement for nominal scales, Educational and Psychological Measurement 1960; 20: 37-46.

6. Schouten HJA. Nominal scale agreement among observers. Psychometrika 1986; 51: 453-466.

7. Cahen J. Weighted kappa: nominal scale agreement with provision for scaled disagreement or partial credit. Psychol Bull 1968; 70: 213-230.

8. Fleiss JL. Statistical methods for rates and proportions. 2nd edition, New York: John Wiley \& Sons, 1981.

9. Fleiss JL. The design and analysis of clinical experiments. New York: John Wiley \& Sons, 1986. 



\section{Chapter 7}

\section{EPILOGUE}

This last chapter discusses the contribution of epidemiological studies to the evidence for a causal relation between beta-carotene and cancer.

First an outline is given of the biomedical evidence for such a causal relation. Next the evidence from epidemiological studies will be discussed, concentrating on the strengths and weaknesses of non-experimental and experimental studies. Finally it will be described how the author's belief in a causal relation between beta-carotene and cancer was changed by the empirical evidence presented in this thesis, after which expectations for the future will be discussed.

\section{Biomedical evidence}

Free radicals are thought to play an important role in carcinogenesis, as they may damage DNA and RNA, and membrane structures. They are formed as byproducts of normal cell metabolism but may also be induced by external factors such as drugs, radiation and xenobiotics. Because of the ubiquity of molecular oxygen in aerobic organisms and its ability to accept electrons readily, oxygen radicals are often the mediators of cellular free radical reactions. Therefore it is supposed that antioxidants form a defense mechanism against cell damage caused by free radicals. Beta-carotene is an important antioxidant as it is an efficient oxygen scavenger and inhibits lipid peroxidation (1). This antioxidant mechanism would seem to be a plausible explanation for the presumed anticancer effects of beta-carotene. But, as discussed in chapter 2, it would also be possible that beta-carotene exerts its effect after conversion into retinol. Laboratory experiments with various carotenoids have indicated that for some anticancer effects conversion into retinol is required, while in other situations carotenoids without vitamin A activity exert a protective effect (2,3). Apparently different mechanisms of cancer prevention are involved, depending on the way cancer is induced. As it is unclear to what extent various mechanisms of cancer induction contribute to human carcinogenesis, it is uncertain whether beta-carotene exerts its effect as beta-carotene or after conversion into retinol.

A critical point in cancer prevention is the relevant period for action. Most experts believe that carcinogenesis is a long lasting multi-stage process. Cancer is regarded as the end-point of a series of changes and/or actions. This view has originated from animal experiments in which several stages could be identified. The most simple distinction is between an initiation and a promotion stage. Tumor initiation is caused by irreversible, rapidly accomplished, cellular changes due to exposure to a carcinogen in low quantities or for short durations. Promotion requires repeated exposure to 
promoting agents at short intervals; if the interval between exposure is prolonged, the effects are reversible. Promotors induce tumor development only after initiation, even if a long interval separates the two stages; promotion in the absence of or prior to initiation will not result in tumor formation.

Where in this process could beta-carotene exert its effect? This again depends on the mechanism of the cancer preventive effect. Beta-carotene may play its antioxidant role wherever oxygen radicals are involved in the cancer process. These radicals are known to affect both the initiation and the promotion stage (4). Thus an effect is possible in both stages. However, as mentioned above, it is also possible that beta-carotene exerts its cancer preventive effect after conversion into retinol. Retinol and its synthetic derivates, the retinoids, are known to play a role in the promotion stage, but have not been shown to be involved in tumor initiation. Thus the promotion stage is affected independently of the mechanism involved, whereas only beta-carotene itself is supposed to be able to influence the initiation stage.

The distinction between initiation and promotion is very helpful in experimental animal studies, but in human carcinogenesis the distinction is less obvious: do premalignant stages in humans correspond to the promotion phase in animal experiments? Are there irreversible stages? Which stages of the cancer process are reversible? In human carcinogenesis we may distinguish factors influencing early and late stages of the cancer process.

It has been shown in human experiments that retinoids affect the very late stages of the cancer process, since regression of premalignant lesions of skin and oral mucosa was observed after treatment with these agents (5). The reversibility of the premalignant stage is illustrated by its rapid disappearance after treatment with retinoids, but also by the rapid recurrence of the lesion when the medication is stopped. The effects of retinoids on cervical dysplasia have so far only been studied in phase II trials, using topical application methods (5).

For the interpretation of the results of our experiment, in which we studied the effect of beta-carotene on the regression and progression of cervical dysplasia, it is of crucial importance whether beta-carotene is able to influence this part of the cancer process, either by inducing regression or inhibiting progression. If the effect is exerted after conversion into retinol, it is most likely that it does affect regression of the premalignant stage, as was observed in other experiments (5). If the effect is exerted by beta-carotene it is not known whether it influences this part of the cancer process, because results of randomized experiments on beta-carotene have not been published yet.

Another important question is whether beta-carotene protects against all types of cancer at all sites. This again depends on the way cancer is induced and the mechanism of the anticancer effect. Animal experiments have shown that the cancer preventive effectiveness of retinoids depends on the type of retinoid, the target tissue and the 
mechanism of cancer induction. The effect of beta-carotene has so far been studied mainly for UV-induced skin tumors in mice, showing a protective effect. But even in these skin tumors, its effect appears to depend on the type of carotenoid and the mechanism of cancer induction (2).

Thus laboratory experiments have shown that it is quite possible that beta-carotene protects against cancer. This, however, does not yet prove an anticancer effect of betacarotene in humans. We certainly cannot do without epidemiological evidence to assess the impact of beta-carotene in human carcinogenesis.

\section{Epidemiological evidence}

From non-experimental epidemiological studies it appears that persons with a low vegetable and fruit consumption run an increased risk to contract various types of cancer $(6,7)$. On the nutrient level, cancer incidence has been found to be inversely associated with the intake of beta-carotene, but also with the intake of vitamin $C$, dietary fibre and other related compounds present in or associated with vegetables and fruits.

Thus the results of epidemiological studies on beta-carotene are consistent with the evidence from laboratory experiments. However, this still does not mean that the relation between beta-carotene and cancer is causal. Any dietary or other factor associated with the consumption of vegetables and fruits is a possible rival, especially if a plausible mechanism of action can be put forward.

We will discuss the contribution of non-experimental and experimental studies to the evidence that beta-carotene is causally related to cancer.

\section{Non-experimental studies}

In studies on dietary factors and cancer, information is collected about the consumption of various food. items, usually by questionnaire. Next this information is translated into the intake of nutrients or other food components. This translation into food components is hampered by regional and seasonal variations in composition of foods, and usually by the lack of information about meal preparations, resulting in imprecise information. But more importantly, food composition tables present only a limited number of food components. For example, the observation that a low consumption of vegetables and fruits is often associated with a high cancer incidence, has directed the attention towards the intake of beta-carotene, vitamin $\mathrm{C}$ and dietary fibre, among other things because these food components are listed in most food tables. However, it is quite possible that other factors present in vegetables and fruits, but not listed in food tables, such as indoles, are responsible for the anticancer effect.

Apart from this problem of collecting the precise and relevant information, bias may occur due to imperfect recall of the study subjects of their dietary 'exposure'. This is 
especially important in studies with retrospective collection of exposure data, as is usually the case in case-control studies. Cases and controls may give different reports of their food consumption, even in the absence of a relation between certain food habits and cancer, e.g. because cases are influenced by their disease status or because interviewers approach cases and controls differently. For the sake of convenience and to reduce recall bias, dietary information is usually obtained over the period just before diagnosis of the disease, either presuming that this is the etiologically relevant moment, or presuming that current food habits reflect food habits in the past.

A comparable degree of imprecise recall in cases and controls leads to underestimation of the effect, whereas differential recall bias in cases and controls may lead to either underestimation and overestimation.

In cohort studjes, recall bias is less of a problem, since information about (usually current) dietary habits is obtained long before the diagnosis of cancer. However, the abovementioned problems with respect to collecting precise and relevant information about the intake of dietary factors, occur to the same extent as in case-control studies.

An issue that plagues both case-control and cohort studies is confounding bias. Theoretically, confounding can, if not prevented by the study design, be adjusted for in the analysis. In practice this is only true for confounding factors that are known and properly measured.

Confounding bias may cause either underestimation or overestimation of the effect. If a confounding dietary factor, (for example vitamin $\mathrm{C}$ ) is positively associated with the dietary factor under study (for example beta-carotene), because these dietary factors chiefly occur in the same foods, and if their relations with the disease status have the same direction (for example both negatively associated) then the effect of one factor may totally disappear by adjustment for the other factor. Moreover, at high correlations between both factors adjustment is impossible.

These highly associated factors (known or unknown) form a major drawback of nonexperimental studies on dietary factors in relation to disease incidence.

What, then, is the causal evidence from non-experimental epidemiological studies? Hill suggested criteria to distinguish causal from non-causal associations in non-experimental epidemiological studies (8). Here we will discuss the most important of these in relation to studies of dietary factors: strength, consistency, biological gradient and plausibility.

1. Strength of the association refers to the estimated magnitude of the risk parameters. Strong associations are more likely to be causal than weak associations. The underlying idea is that if they were due to confounding or some other bias, the factor inducing bias would have to be strong and would therefore presumably be evident. Weak associations, on the other hand, are more likely to be explained by undetected biases. The risk ratios in studies on dietary factors and cancer are usually weak (close to 1 ), so they can easily be due to various biases. 
2. Consistency refers to the repeated observation of an association in different populations under different circumstances. The underlying idea is that bias does not occur to the same extent in all studies, for one thing because potential confounding factors show different associations with the factor under study in different studies. Although this may be correct in some situations, it certainly is not true for etiological studies on dietary factors and cancer. The most important confounding dietary factors, associated with the presumed causal dietary factor will reappear in every study, because they chiefly occur in the same foods.

3. Biological gradient refers to the presence of a dose-effect curve. Associations showing a dose-effect trend are not necessarily causal: confounding can result in a trend between a non-causal risk factor and the disease if the confounding factor itself also demonstrates a biological gradient in its relation with the disease. This is quite conceivable if dietary factors are studied.

4. Plausibility implies that epidemiological observations do not conflict with what is known about the mechanism by which the disease develops. This is an important criterium as it integrates biomedical and epidemiological evidence. If no plausible explanation can be given the probability that a relation is causal will be lower. Attention is then usually focused on undetected confounding factors. However, the absence of a biological explanation at this moment does not mean that no such mechanism exists.

Hill's criteria for causality are obviously not very helpful when dietary factors are being studied in relation to cancer. The presence of associated dietary factors, occurring mainly in the same foods, can explain both a biological gradient and consistency. In addition, the interpretation of consistency can be seriously hampered by selective publication. Authors tend to emphasize their positive results, whereas negative findings or results which contradicts prevailing knowledge are omitted or are not given much attention. This is especially important in common non-experimental etiological research, in which a plethora of associations is studied, trying to establish a relation between the exposure to numerous risk factors and one or many diseases. Moreover, referents or editors may have a preference for publishing research that shows statistically significant results and/or results in agreement with existing knowledge. This publicaton bias further devaluates the consistency criterium.

In conclusion, uncertainties about the presence, direction and extent of bias seriously hamper the interpretation of the non-experimental studies. Therefore, the value of the empirical evidence of these studies in showing a causal relation is limited.

\section{Experimental studies}

In experimental studies the problems of bias can be eliminated by the study design. Such studies are therefore much more powerful in assessing the causality of a relation. However, the performing of experiments on humans is severely hampered by its feasibility, mainly due to ethical and practical problems. 
For ethical reasons, only experiments on dietary factors with potentially favorable effects on cancer incidence are considered justified. In such experiments presumably protective dietary factors may be administered as supplements in double-blind experiments. On the level of food components, studies of presumably risk-enhancing factors are impossible, as one cannot delete one single factor from the diet.

For practical reasons, only the effects on events with a rather high incidence rate can be studied, since events with a low incidence rate require too large a study population. Moreover, the events must be observable within a reasonably short period; too long a follow-up period also makes the experimental approach impracticable.

These feasibility issues lead to specific choices in the study design with regard to study popullations, outcome parameters, or stage of the cancer process studied. These choices may pose problems for the external validity of the experimental studies.

\section{My belief in the causality of the relation}

The motive of scientific research is trying to understand reality by developing theories about it. By postulating hypotheses and testing them, the belief in theories is increased or decreased. Individual studies aim at changing the belief in a certain theory. The extent of change depends on the validity and the outcome of the study. When the studies presented in this thesis were started, there was some evidence that beta-carotene protects against cancer. This belief was based on the rather consistent observation in non-experimental epidemiological studies of an inverse relation between the intake of dietary beta-carotene and the incidence of cancer, as well as on the evidence from laboratory experiments. The results of our non-experimental and experimental studies both contradict the theory that beta-carotene protects against cancer. To what extent has this changed my belief in the causal relation between betacarotene and cancer?

In my opinion, the results of the case-control study do not carry much weight, because it is difficult to adjust properly for important confounders. The substantial changes of the odds ratios in our case-control study after adjustment for the confounders measured (chapter 3) show the sensitiveness of the relations to confounding. Experimental studies are much more powerful in increasing the evidence for causal relations. Thus if betacarotene had shown a favorable effect on the regression of cervical dysplasia, I would have been almost convinced that beta-carotene protects against cancer. However, the negative results in our experiment do not necessarily preclude a causal relation between beta-carotene and cancer. Some choices in the study design may have prevented the demonstration of an effect, as discussed in chapter 5. However, alternative explanations are that beta-carotene does not influence this stage of the cancer process or, more unlikely, it does affect cancer but not cervical cancer.

Thus my belief in the causality of the relation has certainly not been increased. On the contrary, it has been decreased by the results of the studies presented. 


\section{Expectations for the future}

As discussed above, I think that future non-experimental epidemiological studies do not have the potential to shed more light on the causality of the relation between betacarotene and cancer. The uncertainties about presence, direction and extent of bias hamper the interpretation of the results, and associated dietary factors especially form a major problem in the assessment of causality.

In my opinion, only well designed experimental studies in humans have the power to decide further about the role of beta-carotene in cancer prevention. At this moment, a number of randomized experiments is in progress, studying the effect of beta-carotene on precancerous stages or on the incidence of cancer. Their empirical evidence will help us in finally making up our minds. 


\section{References}

1. Burton GW, Ingold KU. Beta-carotene: an unusual type of antioxidant. Science 1984; 224: $569-572$.

2. Mathews-Roth MM. Antitumor activity of beta-carotene, canthaxanthin and phytoene. Oncology 1982; 39: 33-37.

3. Stich HF, Stich W, Rosin MP, Vallejera MO. Use of the micronucleus test to monitor the effect of vitamin A, beta-carotene and canthaxanthin on the buccal mucosa of betelnut/tobacco chewers. Int J Cancer 1984; 34: 745-750.

4. Ames BN. Dietary carcinogens and anticarcinogens. Oxygen radicals and degenerative diseases. Science 1983; 221: 1256-1264.

5. Lippmann $\mathrm{SM}_{4}$ Kessler JF, Meyskens FL. Retinoids as preventive and therapeutic anticancer agents (part II). Cancer Treat Rep 1987; 58: 493-515.

6. Byers T, Graham S. The epidemiology of diet and cancer. Adv Cancer Res 1984; 11: $1-68$.

7. Willett WC, MacMahon B. Diet and cancer - an overview. New Engl J Med 1984; 30: 633-638.

8. Hill $\mathrm{AB}$. The environment and disease: association or causation? Proc R Soc Med 1965; 58: 295-300. 


\section{Chapter 8}

\section{SUMMARY}

The central question of this thesis is whether beta-carotene protects against cancer.

Chapter 1 discusses the validity of non-experimental and experimental studies of dietary factors, by way of background information for the studies presented in this dissertation. In addition, the content of the various chapters is briefly described.

Chapter 2 presents a review of the role of vitamin A in cancer prevention. It appears that beta-carotene is more likely to be responsible for the cancer preventive effect than retinol. This observation is consistent with current knowledge about their metabolisms: a high intake of retinol leads mainly to storage in the liver and therefore hardly influences the serum level of retinol, whereas a high intake of beta-carotene is reflected in a high serum level of beta-carotene. With regard to the cancer preventive effect, several mechanisms have been postulated, for the effects of both carotenoids and retinol. Epidemiological studies indicate that a high intake of beta-carotene reduces cancer risk. It is unclear, however, whether the effect is exerted by beta-carotene itself or after conversion into retinol.

In order to gain more insight into the causality of the relation between beta-carotene and cancer, we performed a randomized experiment. We chose to study the effect of a supplemental dose of beta-carotene on the regression and progression rates of cervical dysplasia. About 300 women with cervical dysplasia participated in this experiment. They filled in a postal questionnaire inquiring about all presumed risk factors for cervical dysplasia, including sexual habits, smoking habits and a number of food habits. With respect to the latter, we inquired particularly about the consumption of foods containing beta-carotene, retinol, vitamin $\mathrm{C}$ or dietary fibre. We mailed the same questionnaire to a sample of the general population. This enabled us to perform, in addition to the experiment, a case-control study of the role of beta-carotene and other dietary factors in the etiology of cervical dysplasia. The results of this non-experimental study are presented in chapter 3 . The data of 257 patients and 705 controls could be analyzed. After adjustment for many confounders, we observed, to our surprise, an increased risk of cervical dysplasia for women with a high intake of beta-carotene $(\mathrm{OR}=2.3$; $95 \% \mathrm{CI}: 1.3-4.2)$. No consistent relation was found with the intake of retinol, while the relations with vitamin $\mathrm{C}$ and dietary fibre were weakly negative, but not statistically significant. These findings do not support the hypothesis that beta-carotene protects against cervical dysplasia. 
Chapter 4 presents the rationale and implications of the design of the randomized experiment. Attention is paid among other things to the choice of cervical dysplasia, of the outcome parameter, of the duration of the intervention period and of the dose of beta-carotene. The consequences of these choices for the interpretation of the results are discussed.

Chapter 5 presents the results of the randomized experiment. A total of 369 patients were admitted, of which 278 turned out to be suitable for data analysis. The experimental group $(\mathrm{N}=137)$ received a supplemental daily dose of $10 \mathrm{mg}$ of betacarotene in a capsule for three months. The control group $(\mathrm{N}=141)$ received placebo capsules. The outcome parameter was based on the change in degree of dysplasia, comparing the histological diagnosis before admission with the histological or cytological diagnosis after the intervention period. To improve the precision of the outcome parameter all histological slides were revised by one pathologist. Moreover, two definitions of regression and progression were used. The number of patients showing progression was too small to allow conclusions. No statistically significant effects on the regression rates were observed. Using the broad definition of regression, the group receiving beta-carotene showed slightly less regression ( $\mathrm{OR}=0.7 ; 95 \% \mathrm{CI}: 0.3-1.6)$. Using the strict definition the beta-carotene group showed slightly more regression ( $O R=1.2$; $95 \% \mathrm{Cl}: 0.4-3.4$ ). A secondary analysis in which the total intake of beta-carotene (diet and supplements) was studied in relation to the regression rates of cervical dysplasia did not show a protective effect either. Some critical choices in the study design and performance are discussed as possible explanations for the negative result. Alternative explanations are that beta-carotene does not affect this specific part of the cancer process or is not effective on cervical cancer. But it is also possible that beta-carotene is not causally related to cancer at all, and that the associations found in many nonexperimental epidemiological studies were due to insufficiently controlled bias.

Chapter 6 presents the results of a study of the interobserver variation in the interpretation of biopsy specimems of cervical tissue. Four experienced pathologists examined the same set of 106 histological slides and assigned them to one of five diagnostic categories: no dysplasia, mild dysplasia, moderate dysplasia, severe dysplasia, and carcinoma in situ. We calculated kappa values to take chance agreement into account. Unweighted group kappa was 0.28 and weighted group kappa was 0.56 . There was considerable disagreement among the pathologists. Explanations for the interobserver variation may be sought in the equivocal criteria for grading cervical dysplasia, and the arbitrary division of a continuous process into distinct categories.

In chapter 7 the contribution of epidemiological studies to the evidence of a causal relation between beta-carotene and cancer is discussed. After presenting the evidence from laboratory experiments, the value of epidemiological studies of dietary factors is discussed. Non-experimental studies are hampered by various sources of bias, of which confounding by associated dietary factors is probably the most important. These 
associated factors seriously affect the usefulness of Hill's criteria to assess causality in non-experimental epidemiological studies.

Experimental study designs can eliminate these biases. Therefore, experiments are much more powerful in establishing a causal relation.

At the end of the chapter, the author's personal view is given. Her belief in a causal relation between beta-carotene and cancer has been decreased by the results of the studies, presented in this thesis. With respect to the future, it is her opinion that additional non-experimental studies do not have the potential to shed more light on the causality of the relation. Only experimental studies will give further evidence whether it has been right or wrong to believe that beta-carotene protects against cancer. 



\section{Chapter 9}

\section{SAMENVATTING}

Dit proefschrift gaat over de rol van beta-caroteen bij de preventie van kanker. Betacaroteen is een voedingsstof die in groenten en, in mindere mate, ook in fruit voorkomt. De belangrijkste bronnen van beta-caroteen zijn worteltjes, boerenkool, spinazie en andere donkergroene bladgroenten. Beta-caroteen is een voorloper van vitamine $A$. Het is namelijk zo dat een deel van beta-caroteen in het lichaam omgezet wordt in retinol. Retinol is de wetenschappelijke naam voor vitamine A.

Retinol zit in dierlijke produkten zoals lever, vlees, eieren en zuivelprodukten. In groenten en fruit komen carotenoïden voor. 'Carotenoïden' is een verzamelnaam voor een aantal verwante stoffen, waarvan beta-caroteen de belangrijkste is. Zoals gezegd wordt een deel van de carotenoïden in het lichaam (met name in de darmen en de lever) omgezet in retinol. Een ander deel van de carotenoïden dat in het lichaam wordt opgenomen wordt niet omgezet in retinol, maar blijft in het lichaam aanwezig in de vorm van carotenoïden.

Om te beginnen is het tot dusver uitgevoerde onderzoek naar de rol van vitamine $\mathrm{A}$ bij het ontstaan van kanker bestudeerd en samengevat. Uit dit onderzoek komen aanwijzingen dat vitamine $A$ beschermt tegen de ontwikkeling van kanker. De belangrijkste vraag bij de bestudering van deze onderzoekingen was of retinol dan wel beta-caroteen verantwoordelijk is voor het vaak waargenomen preventieve effect op de ontwikkeling van kanker. Uit een flink aantal onderzoekingen bij mensen bleek dat personen die veel groenten en fruit (beta-caroteenrijk) aten, minder kans hebben om kanker te krijgen dan personen die weinig groenten en fruit aten. Personen die veel dierlijke produkten (retinolrijk) aten, bleken een even grote kans op kanker te hebben als personen die weinig van deze produkten aten. Dit komt overeen met het lot van retinol en beta-caroteen in het menselijk lichaam. Retinol wordt grotendeels opgeslagen in de lever. Daarom wordt de hoeveelheid retinol die de andere weefsels bereikt, niet groter als er meer retinol in de voeding zit. Het deel van beta-caroteen dat hiet wordt omgezet in retinol, is wel goed in staat om alle weefsels te bereiken. Daarnaast zijn er vele dierproeven en andere laboratoriumexperimenten gedaan om er achter te komen op welke manier beta-caroteen en retinol zouden kunnen beschermen tegen kanker. Voor beide stoffen bleken op grond van deze experimenten verschillende mechanismen voorstelbaar te zijn. Voor een effect van retinol (of daarvan afgeleide stoffen) zijn meer mogelijke mechanismen bekend dan voor een effect van beta-caroteen. Samengevat kan uit het tot dusver verrichte onderzoek geconcludeerd worden dat het aannemelijker is dat het vaak geconstateerde beschermend effect veroorzaakt wordt door veel beta-caroteen in de voeding dan door veel retinoll in de voeding. Het is nog onduidelijk of het uiteindelijke effect op de weefsels waarin kanker ontstaat, 
uitgeoefend wordt door beta-caroteen of dat het daarvoor toch eerst omgezet moet worden in retinol. Deze omzetting zou dan moeten gebeuren nadat beta-caroteen de lever gepasseerd is.

De centrale vraag in dit proefschrift is of beta-caroteen werkelijk beschermt tegen kanker, met andere woorden of er sprake is van een oorzaak-gevolg relatie. Omdat het nu eenmaal niet mogelijk is om alles tegelijkertijd te onderzoeken, hebben we ons beperkt tot dysplasie van de baarmoederhals. Dysplasie betekent dat er sprake is van een verstoring van de weefselopbouw door een afwijking in de groei en de ontwikkeling van een weefsel. Dysplasie van de baarmoederhals wordt beschouwd als een voorstadium van baarmoederhalskanker. Dat voorstadium zal bij een aantal vrouwen op den duur overgaan in echte kanker, maar er bestaat ook een kans dat het weefsel na verloop van tijd weer normaal wordt. In een uitstrijkje, waarbij losse cellen van het weefsel van de baarmoederhals geschraapt worden, kan men zien of er sprake is van dysplasie. Nog beter is dat te beoordelen op grond van een heel klein stukje weefsel dat uit de baarmoederhalls gehaald wordt (weefselpreparaat). Afhankelijk van de ernst van de verstoring van de weefselopbouw maakt men onderscheid tussen lichte, matige en ernstige dysplasie. Wanneer de afwijking nog ernstiger is spreekt men van "carcinoma in situ", en tenslotte van kanker.

We hebben een tweetal onderzoekingen uitgevoerd om na te gaan of beta-caroteen invloed heeft op dysplasie van de baarmoederhals: een experimenteel en een nietexperimenteel onderzoek.

Het essentiêle kenmerk van een experiment is dat de onderzoeker zelf actief ingrijpt in de onderzoekspopulatie, en daarna het effect daarvan bestudeert. In het experiment hebben we de helft van de vrouwen met dysplasie van de baarmoederhals extra betacaroteen gegeven waarna we vaststelden of het stadium van dysplasie ernstiger werd, gelijk bleef of minder ernstig werd. Als het ernstiger werd, noemden we dat progressie van het dysplasiestadium, terwijl de term regressie werd gebruikt als het stadium minder ernstig werd.

In een niet-experimenteel onderzoek observeert de onderzoeker alleen maar wat er gebeurt in de onderzoekspopulatie, zonder er zelf iets aan te veranderen. In ons geval zijn we in het niet-experimentele onderzoek nagegaan, of vrouwen met dysplasie van de baarmoederhals andere voedingsgewoonten hadden dan vrouwen zonder deze aandoening. Een dergelijk onderzoek wordt een patiënt-controle-onderzoek genoemd. De resultaten van het patiënt-controle-onderzoek en het experiment zullen hier nu beschreven worden.

In het patiẻnt-controle-onderzoek waren de patiënten de vrouwen met dysplasie van de baarmoederhals die ook aan het experiment deelnamen. De controlegroep bestond uit een steekproef van vrouwen uit de algemene bevolking. Alle vrouwen vulden eenzelfde vragenlijst in die informeerde naar de consumptie van een aantal voedingsmiddelen, met name produkten die rijk zijn aan beta-caroteen, retinol, vitamine $C$ en voe- 
dingsvezel. Daarnaast werd gevraagd naar een aantal vermoedelijke risicofactoren van dysplasie van de baarmoederhals, waaronder rookgewoonten en bepaalde sexuele gewoonten. De reden dat we niet alleen naar voedingsgewoonten hebben gevraagd, maar ook informatie hebben verzameld over andere risicofactoren was dat we bij het vaststellen van de invloed van beta-caroteen met die andere risicofactoren rekening wilden houden. De gegevens van 257 patiënten konden worden vergeleken met die van 705 controlepersonen. Tot onze verrassing bleek dat de vrouwen met dysplasie van de baarmoederhals meer beta-caroteen met hun voeding binnenkregen dan de vrouwen in de controlegroep. Hieruit kan geconcludeerd worden, dat de vrouwen die veel betacaroteen in hun voeding hadden meer kans hadden om dysplasie van de baarmoederhals te krijgen, dan vrouwen van wie de voeding weinig beta-caroteen bevatte. Rekening houdend met andere riskante gewoonten bleek deze kans ruim twee keer zo groot te zijn. We vonden geen verband met de hoeveelheid retinol in de voeding. De vrouwen van wie de voeding veel vitamine $C$ of veel voedingsvezel bevatte hadden een iets kleinere kans om dysplasie van de baarmoederhals te krijgen dan vrouwen van wie de voeding weinig van deze voedingsstoffen bevatte. Deze resultaten suggereren dat de voedingsstof in groenten en fruit die verantwoordelijk is voor het beschermend effect tegen kanker, vermoedelijk niet beta-caroteen zal zijn.

Voor het experimentele onderzoek werden in totaal 369 patiënten aangemeld vanuit 23 ziekenhuizen. Deze patiënten hadden zelf toegestemd om aan het onderzoek mee te doen. Uiteindelijk konden de gegevens van 278 patiënten gebruikt worden voor het vaststellen van het effect van beta-caroteen. Deze vrouwen waren door loting over twee groepen verdeeld: een experimentele groep van 137 vrouwen en een controlegroep van 141 vrouwen. De experimentele groep kreeg dagelijks, gedurende drie maanden, een extra dosis van $10 \mathrm{mg}$ beta-caroteen in de vorm van capsules. De controlegroep ontving placebo-capsules die er hetzelfde uitzagen als de beta-caroteen capsules, maar waarin geen beta-caroteen zat. Voordat de vrouwen aan het onderzoek konden meedoen, was op grond van een weefselpreparaat vastgesteld dat ze inderdaad dysplasie hadden en werd vastgelegd in welk stadium de dysplasie verkeerde. Na drie maanden werd onderzocht of de ernst van dysplasie was toegenomen of afgenomen. Daartoe werd een uitstrijkje gemaakt en vaak ook opnieuw een weefselpreparaat. $\mathrm{Om}$ de betrouwbaarheid van de beoordelingen te verhogen werden alle weefselpreparaten achteraf door éen patholoog beoordeeld. Bovendien gebruikten we twee definities van regressie en progressie. $\mathrm{Er}$ was een ruime definitie waarbij iedere verandering van het dysplasiestadium regressie of progressie genoemd werd, en een strenge definitie waarbij alleen de grotere veranderingen in ernst van dysplasie als regressie of progressie werden aangemerkt. Het aantal vrouwen bij wie het dysplasiestadium ernstiger was geworden, bleek te kJein te zijn om conclusies op te baseren. De vrouwen die capsules met betacaroteen gekregen hadden, vertoonden niet duidelijk vaker regressie van het dysplasiestadium dan de vrouwen die de placebo-capsules ontvangen hadden. Wanneer de ruime definitie gebruikt werd, vertoonde de groep vrouwen die beta-caroteen capsules ontvangen had zelfs iets minder vaak regressie van het dysplasiestadium. 
Wanneer de strenge definitie gebruikt werd, vertoonde de beta-caroteen groep iets vaker regressie. Deze kleine verschillen zijn waarschijnlijk aan het toeval toe te schrijven.

Daarna werd de regressie van het dysplasiestadium wergeleken tussen de vrouwen die veel en die weinig beta-caroteen hadden gebruikt gedurende de drie maanden. Daartoe werd de hoeveelheid beta-caroteen die in hun voeding zat, opgeteld bij de hoeveelheid die ze met de capsules binnenkregen. Ook dan werd er geen duidelijk verschil in regressie van het dysplasiestadium gevonden tussen de twee onderzoeksgroepen. Bij de opzet van dit experiment moest om praktische redenen een aantal keuzes gemaakt worden, zoals de lengte van de periode dat de capsules geslikt werden, de dosis beta-caroteen en de keuze voor de verandering in dysplasiestadium als maat voor het effect. Sommige van deze keuzes kunnen mogelijk verklaren waarom we geen duidelijke verschillen gevonden hebben. Andere mogelijke verklaringen zijn dat betacaroteen geen effect heeft op een voorstadium van kanker, of juist niet werkt tegen baarmoederhalskanker terwijl het wel beschermt tegen andere vormen van kanker. Maar een verklaring die zeker niet uitgesloten mag worden is, dat beta-caroteen niet de voedingsfactor in groenten en fruit is die beschermt tegen kanker!

Tijdens het experiment is naar voren gekomen dat de pathologen die de weefselpreparaten moesten beoordelen, het niet altijd met elkaar eens waren. We hebben in een apart onderzoek bekeken hoeveel de beoordelingen van vier ervaren pathologen verschilden als ze dezelfde 106 weefselpreparaten bekeken. Zij kregen de opdracht om deze preparaten in te delen in vijf categorieën: geen dysplasie, lichte dysplasie, matige dysplasie, ernstige dysplasie, en carcinoma in situ. Er bleken aanzienlijke verschillen in de beoordelingen voor te komen. Deze verschillen tussen de pathologen kunnen wellicht verklaard worden door de onduidelijke criteria die gebruikt worden voor de indeling in ernst van dysplasie. Bovendien wordt van hen verwacht dat zij een continu proces zonder natuurlijke grenzen toch in klassen indelen.

Wat hebben de eerdere en de zelf uitgevoerde onderzoekingen nu bijgedragen aan de beantwoording van de vraag of beta-caroteen werkelijk beschermt tegen kanker? De laboratoriumexperimenten hebben aangetoond dat het heel goed mogelijk is dat betacaroteen beschermt tegen kanker. Maar dit betekent niet automatisch dat betacaroteen bij mensen ook daadwerkelijk een rol speelt bij de preventie van kanker. Daarvoor is onderzoek nodig bij groepen mensen. Uit het eerdere niet-experimentele onderzoek kwamen aanwijzingen dat personen die veel groenten en fruit eten, minder kans lopen om baarmoederhalskanker te krijgen dan personen die weinig groenten en fruit eten. Als in plaats van naar groenten en fruit naar de individuele voedingsstoffen wordt gekeken die in deze produkten zitten, vindt men ook meestal dat personen die veel beta-caroteen, vitamine $\mathrm{C}$ en voedingsvezel binnenkrijgen een kleinere kans hebben om kanker te ontwikkelen. Maar welke component is nu verantwoordelijk voor het beschermend effect tegen kanker? 
Het probleem in het niet-experimentele onderzoek is dat de invloed van andere risicofactoren niet kan worden uitgesloten. Personen die veel groenten en fruit eten, hebben misschien nog well meer gezonde gewoonten die hen behoeden voor het krijgen van kanker. Slechts tot op zekere hoogte is het mogelijk om bij de verwerking van de gegevens rekening te houden met de invloed van andere risicofactoren. Het blijft daardoor moeilijk om uit te maken welke factor in groenten en fruit nu verantwoordelijk is voor het beschermend effect, en zelfs of het wel een component in groenten en fruit is, en niet een daarmee samenhangende factor, die beschermt tegen kanker. In experimenteel onderzoek wordt een deel van deze problemen vermeden doordat het toeval bepaalt wie tot de experimentele en wie tot de controlegroep behoort. Alle andere gewoonten en factoren die het risico op kanker beïnvloeden zijn daardoor in principe gelijk verdeeld over de experimentele groep en de controlegroep. Door vervolgens de experimentele groep de factor die men wil onderzoeken extra te geven en de controlegroep niet, is het mogelijk om puur het effect van deze ene factor op zich te bepalen.

Maar ook het experiment heeft nadelen. Lang niet alle vraagstellingen zijn in een experiment te onderzoeken. Bijvoorbeeld als het effect van een mogelijk schadelijke stof in de voeding onderzocht wordt, is het onmenselijk om de helft van de mensen in het onderzoek moedwillig deze stof toe te dienen. Vaak zijn experimenten ook niet uitvoerbaar omdat ze te lang zouden duren of omdat er te veel mensen nodig zouden zijn om een effect te kunnen vaststellen. Daarom moeten er dikwijls beperkende keuzes gemaakt worden om ze wel uitvoerbaar te maken, zoals in ons geval bijvoorbeeld de keuze voor een voorstadium van baarmoederhalskanker en de keuze om het effect reeds na drie maanden te bekijken.

Toen we met onze onderzoekingen begonnen, waren er redelijk wat aanwijzingen dat beta-caroteen zou beschermen tegen kanker. Deze waren vooral afkomstig uit laboratoriumexperimenten en uit niet-experimenteel onderzoek bij mensen. Uit ons eigen onderzoek bleek helemaal niet dat beta-caroteen beschermt tegen de ontwikkeling van kanker. Daarom ben ik op grond van onze eigen resultaten minder gaan geloven in de preventieve werking van beta-caroteen. Bovendien denk ik dat in de toekomst alleen experimenteel onderzoek meer zekerheid kan verschaffen over de vraag of we terecht of onterecht geloofd hebben dat beta-caroteen beschermt tegen kanker. 


\section{DANKWOORD}

Op de omslag van dit proefschrift staat maar ến auteur genoemd. Dit is slechts uiterlijke schijn. Aan het binnenwerk hebben veel personen bijgedragen, die ik allen op deze plaats wil bedanken. Velen daarvan waren anoniem: alle vrouwen met dysplasie van de baarmoederhals die bereid waren om aan ons experiment deel te nemen, en tevens de vrouwen die ten behoeve van het patiënt-controle-onderzoek onze enquete ingevuld hebben. Zonder hun medewerking was dit onderzoek niet mogelijk geweest. Ook onmisbaar waren de gynaecologen die bereid waren om patienten met dysplasie van de baarmoederhals voor mijn onderzoek te enthousiasmeren. Ik dank hen allen voor hun medewerking.

Veel dank ben ik verschuldigd aan Henk de Koning Gans, die in het beginstadium van het onderzoek zijn collega-gynaecologen overtuigde van het nut van dit voedingsexperiment. Zonder hem zou dit onderzoek nooit van de grond gekomen zijn. Bovendien dank ik Ton Hasaart die in een later stadium meereisde om de contacten warm te houden.

Vervolgens gaat mijn dank uit naar de pathologen. Met name naar Dik Willebrand, die alle in het onderzoek betrokken weefselpreparaten herbeoordeeld heeft, en naar Jan Willem Arends, die collega's van andere ziekenhuizen bereid vond om een grote serie weefselpreparaten te beoordelen ter bepaling van de interobserver variatie. Ik heb onze samenwerking zeer op prijs gesteld.

Verder dank ik Frans Merkus, Sjef Lohman en de secretaressen van de afdeling Klinische Farmacie van het Maaslandziekenhuis in Sittard. Zij zaten vier jaar lang jedere dag klaar om patiënten voor ons experiment te randomiseren en ze de juiste capsules te sturen. Gedurende die jaren was ook Monique Koekkelkoren in de weer om de administratie op orde te houden en de nodige gegevens van de gynaecologen te verkrijgen. De compleetheid van onze gegevens is haar verdienste. Ook bedank ik Marjolein Grol die in het laatste stadium op voortvarende wijze meehielp met de dataanalyse en Hubert Schouten die ons van de nodige statistische adviezen voorzag als we vastliepen.

Jan Klerkx zorgde ervoor dat het proefschrift ook voor Engelstaligen zonder haperen te lezen is.

Voor de omwerking van talloze kladjes via regelmatig terugkerende concepten tot deze definitieve versie zijn Thum Aarts, Riny Bodifée en Lia Gray verantwoordelijk. Ik dank jullie voor je professionele werk.

Veel dank verdienen ook mijn beide promotoren, Paul Knipschild en Ferd Sturmans. Ik ben blij dat ik me bij hen in Maastricht in de epidemiologie heb mogen bekwamen. 
Ferd Sturmans wekte in Wageningen mijn interesse voor de epidemiologie met zijn colleges en werkgroepen. Tijdens mijn 'in service' opleiding in de vakgroep Epidemiologie/Gezondheidszorgonderzoek heb ik erg veel geleerd van Paul Knipschild, die met zijn inspirerende en creatieve ideeën het vak en de discussies eromheen levendig houdt. Bovendien dank ik Paul voor zijn intensieve begeleiding en het consciëntieuze commentaar op de diverse manuscripten.

Behalve beide hoogleraren wil ik ook de andere leden van de vakgroep bedanken. De voortdurende discussies en kritische opmerkingen tijdens de refereerbijeenkomsten en in de wandelgangen zijn wan niet te onderschatten waarde.

Twee personen wil ik met name noemen:

Floor van Leeuwen, met wie ik mijn studie in Wageningen heb doorlopen, als waren we een tweeling. Dat onze onderzoeksgebieden nu iets meer uit elkaar lopen heeft niets afgedaan aan onze vriendschap.

Carla Frederiks, die op de meest kritieke momenten ter plekke wist te zijn en bovendien zorgde voor de nodige afleiding.

Beste paranimfen, collegialere vriendinnen kan ik me niet wensen.

Tenslotte wil ik mijn ouders bedanken voor het in mij gestelde vertrouwen. Jullie hebben me altijd de vrijheid gegeven om te doen wat ik dacht dat goed voor me was. 


\section{CURRICULUM VITAE}

Riekie de Vet werd op 10 januari 1956 in Gilze geboren. Zij behaalde in 1974 het diploma Atheneum B aan het Paulus Lyceum in Tilburg. In datzelfde jaar werd begonnen met de studie voeding aan de Landbouwhogeschool in Wageningen. Zij liep stage in 1979-80 in het 'Naylor Dana Institute for Disease Prevention', Valhalla, New York, USA. De studie werd in 1981 cum laude afgesloten, met als doctoralvakken Voeding, Toxicologie en Gezondheidsleer/Epidemiologie. Sindsdien is zij als universitair docent werkzaam bij de vakgroep Epidemiologie/Gezondheidszorgonderzoek van de Rijksuniversiteit Limburg. De uitvoering van het in deze dissertatie beschreven onderzoek heeft een belangrijk deel uitgemaakt van haar werkzaamheden op onderzoeksgebied. Daarnaast vervult zij diverse onderwijstaken binnen de Faculteit der Geneeskunde. 